\title{
Recurring extensional and strike-slip tectonics after the Neoproterozoic collisional events in the southern Mantiqueira province
}

\author{
RENATO P. ALMEIDA ${ }^{1}$, MAURÍCIO G.M. SANTOS ${ }^{2}$, ANTONIO R.S. FRAGOSO-CESAR ${ }^{1}$, \\ LILIANE JANIKIAN $^{3}$ and GELSON L. FAMBRINI ${ }^{4}$ \\ ${ }^{1}$ Departamento de Geologia Sedimentar e Ambiental, Instituto de Geociências, Universidade de São Paulo, \\ Rua do Lago, 562, Cidade Universitária, 05508-080 São Paulo, SP, Brasil \\ ${ }^{2}$ Programa de Pós Graduação em Geoquímica e Geotectônica, Instituto de Geociências, Universidade de São Paulo, \\ Rua do Lago, 562, Cidade Universitária, 05508-080 São Paulo, SP, Brasil \\ ${ }^{3}$ Instituto de Astronomia, Geofísica e Ciências Atmosféricas, Universidade de São Paulo, \\ Rua do Matão, 1226, Cidade Universitária, 05508-090 São Paulo, SP, Brasil \\ ${ }^{4}$ Instituto de Geociências, Universidade Federal de Pernambuco, \\ Avenida Acadêmico Hélio Ramos, s/n, Sala 510, Cidade Universitária, 50740-530 Recife, PE, Brasil \\ Manuscript received on May 10, 2010; accepted for publication on May 30, 2011
}

\begin{abstract}
In Eastern South America, a series of fault-bounded sedimentary basins that crop out from Southern Uruguay to Southeastern Brazil were formed after the main collisional deformation of the Brasiliano Orogeny and record the tectonic events that affected the region from the Middle Ediacaran onwards. We address the problem of discerning the basin-forming tectonics from the later deformational events through paleostress analysis of more than 600 fault-slip data, mainly from the Camaquã Basin (Southern Brazil), sorted by stratigraphic level and cross-cutting relationships of superposed striations, and integrated with available stratigraphic and geochronological data. Our results show that the Camaquã Basin was formed by at least two distinct extensional events, and that rapid paleostress changes took place in the region a few tens of million years after the major collision (c.a. $630 \mathrm{Ma}$ ), probably due to the interplay between local active extensional tectonics and the distal effects of the continued amalgamation of plates and terranes at the margins of the still-forming Gondwana Plate. Preliminary paleostress data from the Castro Basin and published data from the Itajaí Basin suggest that these events had a regional nature.
\end{abstract}

Key words: Camaquã Basin, Earth Sciences, Neoproterozoic, Paleostress Analysis, Rift Basin, Southern Brazil.

\section{INTRODUCTION}

The tectonic evolution of Precambrian terrains has long been a major theme of scientific research, but the tectonic record present in the unmetamorphosed and low-grade sedimentary and volcanic successions of the Proterozoic and Archean is frequently underestimated. Studies focused on the

Correspondence to: Renato Paes de Almeida

E-mail:rpalmeid@usp.br paleostress analysis of Precambrian sedimentary basins using fault slip data are scarce, possibly due to the complexity brought by the superposition of several tectonic events during the long geological history of these regions.

In this context, the Ediacaran to Early Cambrian system of fault-bounded basins that crops out from Southern Uruguay to Southeastern Brazil is an ideal object for paleostress analysis since these 


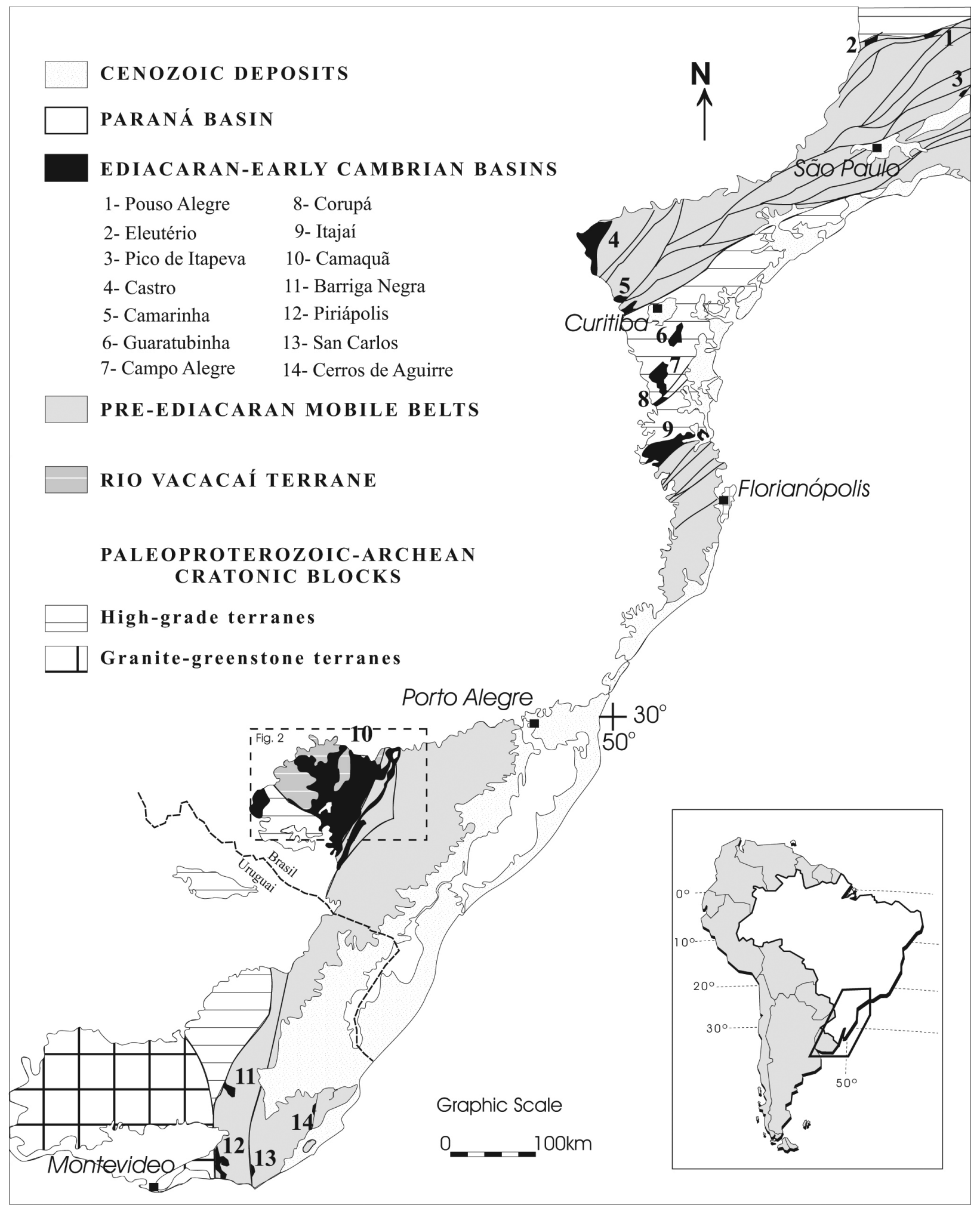

Figure 1: Geological sketch map of southern Brazil and Uruguay showing the location of the Ediacaran-Cambrian basins and the major tectonic division of their basement. 
basins show no regional metamorphism or ductile deformation, and it is possible to identify and date, through geochronological analysis of several volcanic units, distinct events of subsidence bounded by unconformities. This brings the possibility of determining an absolute chronology for the tectonic events that occurred during the basin evolution.

The basin system is more than $1,500 \mathrm{~km}$ long (Fig. 1), encompassing several discontinuous basins bounded by steeply dipping brittle faults and filled with immature terrigenous sedimentary successions with volcanic and volcaniclastic intercalations. The basins are aligned parallel to the major structures of the underlying Dom Feliciano and Ribeira fold belts, which were formed during the main collisional event of the Brasiliano-Pan African Orogeny in the region. This orogenic event affected most of eastern South America, forming several fold and thrust belts around the São Francisco and the Rio de La Plata Cratons (Almeida 1969, Almeida et al. 1973, 1981, Cordani and Brito Neves 1982). The basins were formed soon after the main collisional deformation of the Brasiliano Orogeny, and their origin is often attributed to the last stages of orogenic evolution, being interpreted either as peripheral foreland basins (e.g. Fragoso-Cesar 1991, Gresse et al. 1996, Rostirolla et al. 1999) or post-collisional strikeslip basins (Oliveira and Fernandes 1991, 1992, Machado and Sayeg 1992). These interpretations are based mostly on the presence of strike-slip and inverse faults affecting the sedimentary successions, but no evidence for a syn-depositional nature of this deformation has been presented to date.

In order to test the current models of tectonic evolution of Southeastern South America from the Ediacaran to the Cambrian, we reconstructed the stress evolution of the best preserved basin of the system: the Camaquã Basin, which comprises more than $10,000 \mathrm{~m}$ of sedimentary and volcanogenic successions that record the paleogeographic evolution of the region between ca. $610 \mathrm{Ma}$ and $535 \mathrm{Ma}$. We present orientation data on brittle faults with slickensided fibers and striations of each major unit of the Camaquã Basin, as well as some younger units, in order to establish the chronology of the deformational events and to distinguish the directions of paleostress axes related to basin formation from those that were responsible for its later deformation. The other two major basins of the system were also considered, leading to a regional characterization: the Itajaí Basin, for which we analyzed published paleostress data, and the Castro Basin, for which we collected preliminary data.

The resulting characterization of the basinforming and basin-deforming tectonic events brings new insights on the nature of post-orogenic tectonics. The present work also shows that, given adequate stratigraphic and geochronological controls, paleostress analysis of sedimentary basins can be a powerful tool in the reconstruction of the tectonic history of Precambrian terrains.

\section{Geological Setting}

The Ediacaran to Cambrian basins of Southeastern South America are part of the Mantiqueira Province (Almeida et al. 1981), occurring mainly in its southern part. The Southern Mantiqueira Province comprehends pre-Ediacaran geological units affected by Brasiliano orogenic processes, with peak metamorphism at 630 to $620 \mathrm{Ma}$ (Silva et al. 2005), as well as Ediacaran to Cambrian postOrogenic units, including the here discussed basins and voluminous granites of alkaline affinity (e.g. Philipp 1998, Philipp and Machado 2001, Janasi et al. 2001, Campos Neto 2000, Trouw et al. 2000, Philipp et al. 2002, Nardi and Lima 2002, Leite 2003, Heilbron et al. 2004, Silva et al. 2005, Gualda and Vlach 2007a, b, Oyhantçabal et al. 2007). The preEdiacaran units of the province comprise Archean to Paleoproterozoic blocks with varyied degrees of Neoproterozoic reworking. These include the Rio de La Plata Craton (Almeida et al. 1973) at the southernmost part of the province, an accreted 
intraoceanic terrane of Criogenian age (Rio Vacacaí Terrane of Fragoso-Cesar 1991, São Gabriel Block of Babinski et al. 1996) and a collisional mobile belt (Dom Feliciano Belt, Fragoso-Cesar 1980) with peak metamorphism at the Criogenian - Ediacaran boundary (Basei et al. 2000, Silva et al. 2005), affecting pre-collisional granites and sedimentary basins, as well as their basement. Major strikeslip shear zones, mostly with NNE to NE trends, juxtapose and deform the above described units, including the Ediacaran ones.

The tectonic setting of the Ediacaran to Cambrian basins is controversial, and a series of different models has been proposed for each of the major basin of the system. The currently accepted models can be grouped into three main types: (i) models that consider a syn-orogenic setting, mainly of peripheral foreland basins (e.g. Fragoso-Cesar 1991, Gresse et al. 1996, Rostirolla et al. 1999); (ii) models that consider a late orogenic setting of post-collisional strike-slip basins (Oliveira and Fernandes 1991, 1992, Machado and Sayeg 1992); and (iii) models that consider an extensional origin, unrelated to the previous orogeny (Fragoso-Cesar et al. 2000, 2001, Almeida et al. 2010, Janikian 2001, 2004, Fambrini 2003). Some authors also propose an evolution from syn- to post-orogenic settings recorded in the stratigraphic column of a single basin (e.g. Fragoso-Cesar 1991, Gresse et al. 1996, Paim et al. 2002, Teixeira et al. 2004). The coexistence of such conflicting models is the result of the scarcity of studies on the tectonic record preserved within the basins, since most of the hypotheses are based on models derived from the surrounding metamorphic and plutonic rocks. Indeed, very few paleostress data on these Ediacaran to Cambrian basins have been published (Rostirolla et al. 1992b, Bonacim et al. 1994, for the Itajaí and Castro Basin, respectively).

Despite the potential of the Camaquã Basin to elucidate some important issues concerning the nature of the latest stages of the Brasiliano Orogeny, very few works have focused on the structural analysis of its sedimentary units (e.g. Silva Filho 1997, Fambrini 1998), and the majority of the published tectonic interpretations are based on assumptions of the supposed role of the Camaquã Basin in regional tectonic models (e.g. Fragoso-Cesar 1991, Oliveira and Fernandes 1991, 1992, Gresse et al. 1996). On the basis of stratigraphic analysis of individual units of the Camaquã Basin, recent works (e.g. FragosoCesar et al. 2000, Almeida 2001, Janikian 2001, 2004, Janikian et al. 2003, 2005, Fambrini 2003, Fambrini et al. 2005, Almeida 2005) demonstrated the influence of the syn-sedimentary basin border faults on the depositional architecture. These works revealed the absence of large-scale strike-slip displacement between source-areas and the nearby alluvial-fan deposits, suggesting that the basin border faults were mainly normal during extensional basin-forming tectonic episodes. The here presented characterization of the deformational events that affected the basin brings additional evidence supporting an extensional origin for the Camaquã and coeval basins, which was recently synthesized by Almeida et al. (2010).

\section{METHODS}

For the reconstitution of the paleostress fields, we have collected more than 600 data on faults with striations distributed in more than 100 outcrops (table I) of the volcanic and sedimentary successions of the Camaquã Supergroup (Ediacaran to Cambrian) and the Castro Group, as well as Permian and Triassic successions found near the Camaquã Basin (respectively the Tubarão and the Rosário do Sul groups). In some situations, the data of outcrops within a radius of less than $2 \mathrm{~km}$ were grouped in order to constraint the paleostress tensor with bigger data sets, achieving more accurate results. The successive tectonic events were sorted using relative chronology criteria based on stratigraphic data from the Camaquã Basin and superimposition of slickensided fibers 
and striations. Correlation among basins was based on the available geochronological data (Almeida et al. 2010). We used the TENSOR software (Delvaux and Sperner 2003) to reconstruct the orientation of the paleostress tensors, which is based on the Angelier (1979, 1984, 1990) method of inversion.

\section{CAMAQUÃ BASIN}

The Camaquã Basin is the largest and best known basin of the system, with an area in excess of $3,200 \mathrm{~km}^{2}$ divided into three sub-basins. Detailed published stratigraphic descriptions (e.g. Janikian et al. 2003, 2005, Fambrini et al. 2005, 2006, 2007, Paim and Scherer 2007, Marconato et al. 2009, Almeida et al. 2009) and available geochronological data from several volcanogenic units in different stratigraphic positions (Janikian et al. 2008, 2011, Almeida et al. 2010) are the basis for choosing the Camaquã Basin as the main target for the paleostress analysis. Data from the other basins were interpreted by means of correlation and comparison with the established chronostratigraphic framework of the Camaquã Basin.

The Camaquã Basin (CB) has been studied by many authors, and the evolution of its major units was recognized and related to subsidence and deformation events. Paim (1994) and Paim et al. (2002) divided the CB into five unconformitybounded units (allogroups) gathered in the Camaquã Allosupergroup. They interpreted, based on regional tectonic models, the following subsidence events and related deposits: a foreland succession (Maricá Allogroup); a transpresional strike-slip basin succession presenting inverse faults and folds (Bom Jardim Allogroup); two successions formed during transtensional events (Cerro do Bugio and Santa Bárbara Allogroups); and, finally, a transtensional subsidence event represented by the Guaritas half-graben, which is interpreted as a consequence of the reactivation of NE-SW regional faults (Allogroup Guaritas).
The here adopted stratigraphic column is similar to those proposed by Ribeiro et al. (1966) and Paim et al. (2002), considering published formal lithostratigraphic units (Fragoso-Cesar et al. 2003, Janikian et al. 2003, Pelosi and Fragoso-Cesar 2003, Fambrini et al. 2005, 2006, Fambrini and FragosoCesar 2006, Almeida et al. 2009). The composing units of the Camaquã Supergroup (Fragoso-Cesar et al. 2003) had different depocenters resulted from the activation of distinct syn-depositional faults. This Supergroup is composed of sedimentary and volcanic successions deposited between $\sim 600$ and 530 Ma that are divided into the following units, from base to top: Maricá Group (fluvial sandstones and pebbly sandstones; marine fine-grained sandstones and siltstones), Bom Jardim Group (deep to shallow lacustrine sandstone, conglomerate, rhythmite and mudstone; intermediate, basic and acid volcanic and volcaniclastic rocks), Acampamento Velho Formation (acid volcanic and volcaniclastic rocks), Santa Bárbara Group (alluvial sandstone, conglomerate and sand-mud rhythmite), and Guaritas Group (alluvial sandstone and conglomerate; aeolian sandstone). Basic and intermediate subvolcanic rocks of the Rodeio Velho Intrusive Suite cut across the Camaquã Supergroup, frequently occurring as shallow sills that intrude the Guaritas Group.

\section{STRUCTURAL GEOLOGY}

The Camaquã Basin developed on a complex basement, composed of three structures generated during the Brasiliano event (Fragoso-Cesar 1991): (1) the Rio de La Plata Craton, (2) the Dom Feliciano Belt and (3) the Rio Vacacaí Terrane.

The Rio de La Plata Craton crops to the southwest of the basin and is composed of high grade metamorphic neoarchean and paleoproterozoic rocks (Hartmann et al. 2000). It presents NW/SE banding and highly varied, steep dips.

The craton is bordered to the East by the Dom Feliciano Belt (Ribeiro and Fantinel 1978, Porada 1979, Fragoso-Cesar 1980, 1991, Jost 1981, 


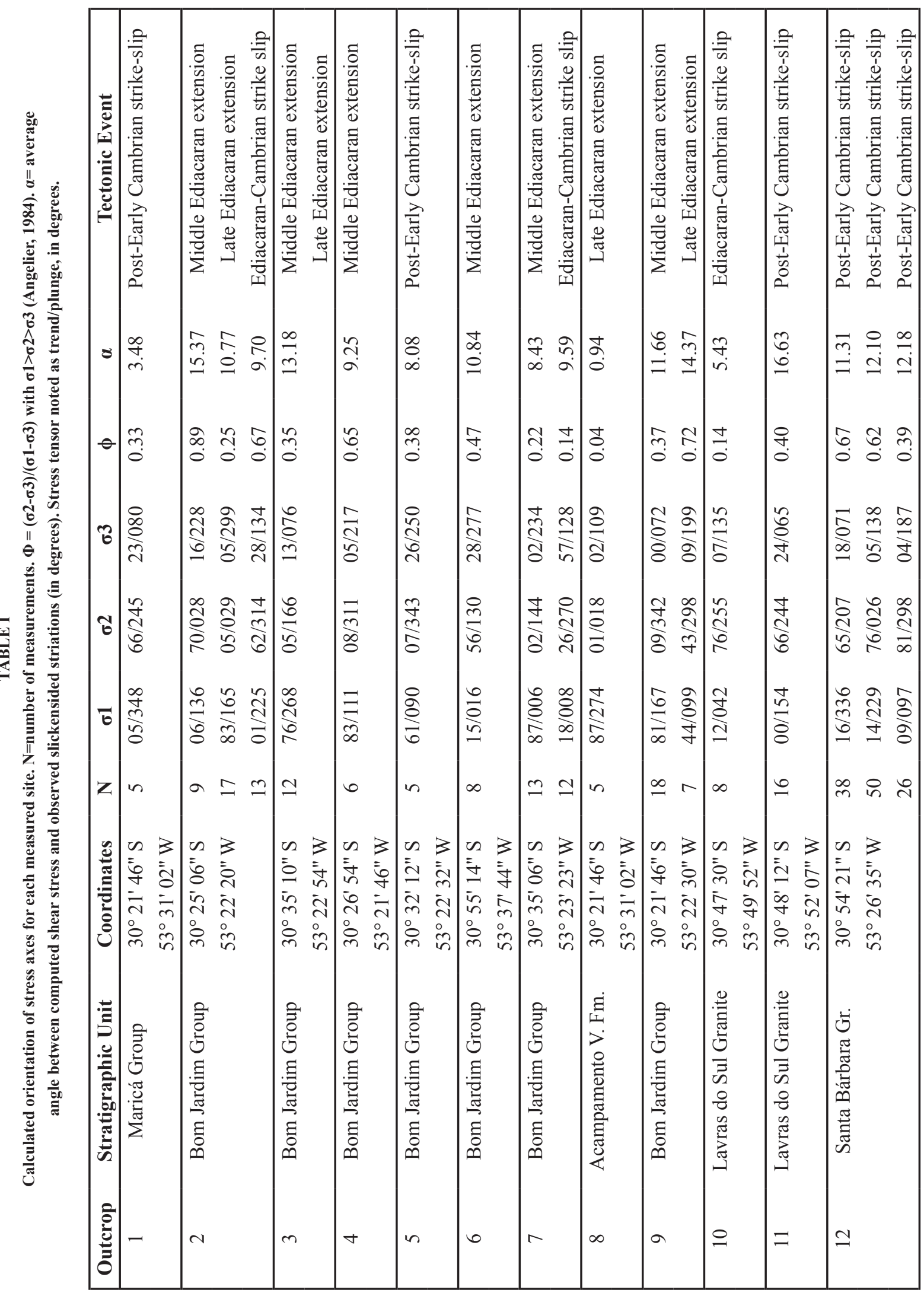




\begin{tabular}{|c|c|c|c|c|c|c|c|c|c|c|c|c|}
\hline 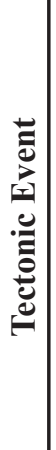 & 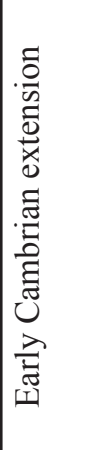 & 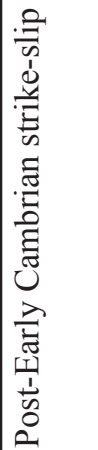 & 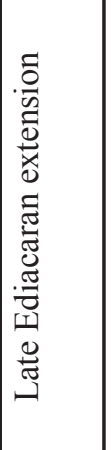 & 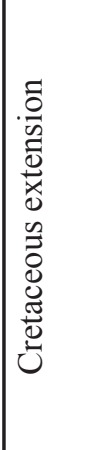 & 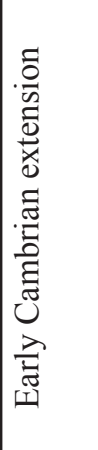 & 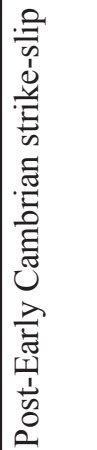 & 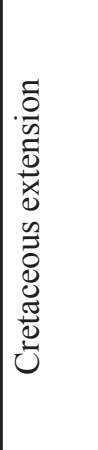 & 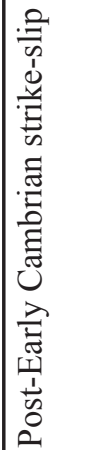 & 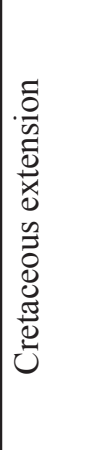 & 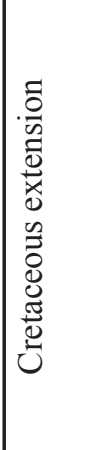 & 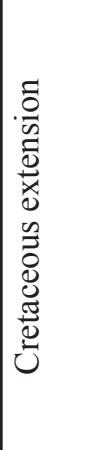 & 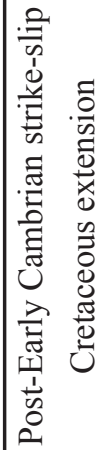 \\
\hline 8 & $\mid \begin{array}{l}n \\
\infty \\
\infty\end{array}$ & $\stackrel{\infty}{\stackrel{\infty}{\Xi}}$ & $\underset{\infty}{\infty}$ & $\stackrel{\vec{m}}{a}$ & $\begin{array}{l}\stackrel{一}{2} \\
\stackrel{2}{2}\end{array}$ & 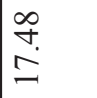 & 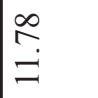 & 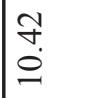 & $\begin{array}{l}\stackrel{0}{\infty} \\
\infty \\
\infty\end{array}$ & $\vec{r}$ & $\begin{array}{l}\tilde{\lambda} \\
\ddot{\beth}\end{array}$ & $\begin{array}{ll}\curvearrowright & \curvearrowright \\
\dot{J} & \circ\end{array}$ \\
\hline$\theta$ & $\frac{R}{0}$ & ¿ & $\frac{0}{0}$ & $\stackrel{\partial}{\circ}$ & $\hat{n}$ & $\stackrel{0}{0}$ & $\frac{0}{0}$ & ?ִ & $\stackrel{\infty}{\circ}$ & 웅. & $\frac{\Delta}{0}$ & $\begin{array}{ll}0 & 8 \\
0 & 0 \\
0 & 0\end{array}$ \\
\hline$\ddot{\theta}$ & $\begin{array}{l}\vec{\infty} \\
\stackrel{\infty}{2} \\
0 \\
0\end{array}$ & 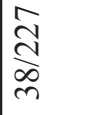 & $\frac{\bar{a}}{\bar{o}}$ & 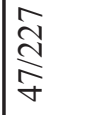 & $\frac{8}{\circ}$ & 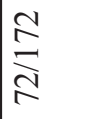 & 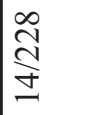 & 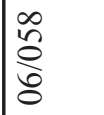 & $\begin{array}{l}\text { tै } \\
\stackrel{2}{8} \\
8\end{array}$ & 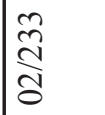 & 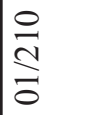 & 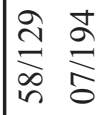 \\
\hline$\widetilde{v}$ & 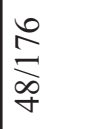 & 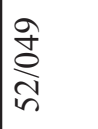 & $\underset{\curvearrowright}{\stackrel{\infty}{\curvearrowright}}$ & $\frac{\stackrel{\wp}{\gtrless}}{\stackrel{r}{r}}$ & 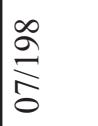 & 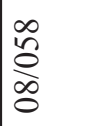 & $\frac{\infty}{\frac{m}{d}}$ & 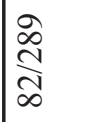 & $\begin{array}{l}\stackrel{ \pm}{\sim} \\
ٍ\end{array}$ & 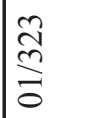 & 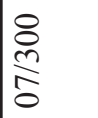 & 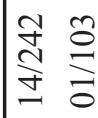 \\
\hline$\overline{6}$ & 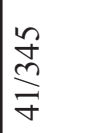 & $\frac{\infty}{\infty}$ & $\begin{array}{l}8 \\
\infty \\
\infty \\
\infty \\
i \\
n\end{array}$ & $\stackrel{\infty}{\stackrel{\infty}{\rightleftharpoons}}$ & $\underset{\infty}{\stackrel{a}{\infty}}$ & 岕 & 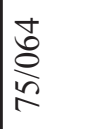 & 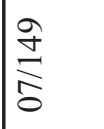 & 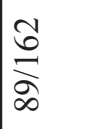 & $\underset{\substack{\infty \\
\infty}}{\stackrel{\infty}{\infty}}$ & $\underset{\infty}{\stackrel{\sim}{\rightleftharpoons}}$ & 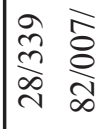 \\
\hline Z & $\vec{\sim}$ & $\simeq$ & $=$ & $\simeq$ & $\Xi$ & $\infty$ & 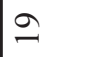 & $\Xi$ & $r$ & 으 & $\approx$ & $r=$ \\
\hline 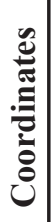 & 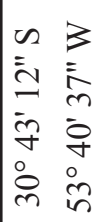 & $\begin{array}{ll}\infty & 3 \\
=0 & i \\
n & 0 \\
i & i \\
0 & n \\
0 & 0 \\
0 & 0 \\
n & i n\end{array}$ & 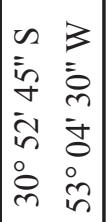 & $\begin{array}{ll}n & z \\
i & \overline{1} \\
n & f \\
\dot{y} & i n \\
y & f \\
0 & 0 \\
0 & n\end{array}$ & $\begin{array}{ll}n & 3 \\
= & 3 \\
7 & \bar{y} \\
0 & m \\
1 & m \\
0 & 0 \\
0 & 0 \\
0 & i n\end{array}$ & 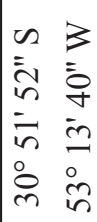 & $\begin{array}{ll}n & 3 \\
\vdots & j \\
0 & j \\
0 & \sigma \\
1 & j \\
0 & 0 \\
0 & 0 \\
n & i n\end{array}$ & 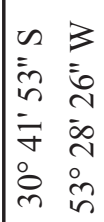 & 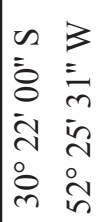 & 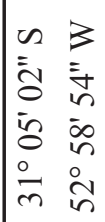 & 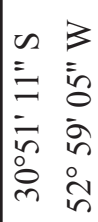 & 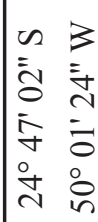 \\
\hline 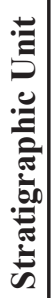 & 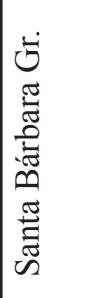 & 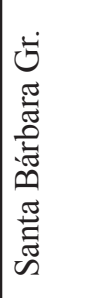 & 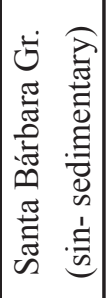 & 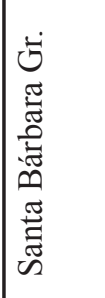 & 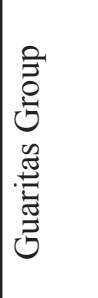 & 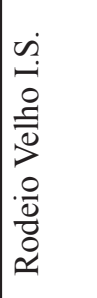 & 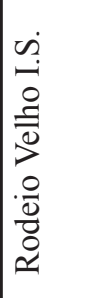 & 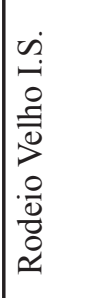 & 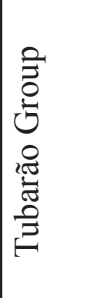 & 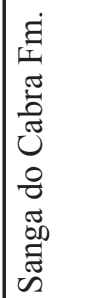 & 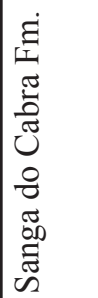 & 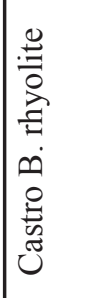 \\
\hline | & \pm & $\because$ & $\stackrel{0}{-}$ & 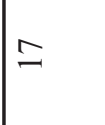 & $\infty$ & ஜ & $\vec{\sim}$ & ปี & $\stackrel{\Xi}{\sim}$ & $\widehat{\sim}$ & $\stackrel{\infty}{\sim}$ & $\bar{n}$ \\
\hline
\end{tabular}


Fragoso-Cesar et al. 1982b, Fernandes et al. 1992). It is interpreted as an intracontinental mobile belt with paleoproterozoic basement, composed of a suite of plutonic-mylonitic rocks with a plataformal covering that presents subordinate volcanism of mesoproterozoic and late proterozoic age, as well as low grade metamorphism. It is affected by large scale folding and shear zones of NE/SW direction. Fernandes et al. (1992) divided the Dom Feliciano Belt into two large-scale continental shear zones: one presenting linear structures with a general E-W trend and a planar fabric with an overall flat-lying attitude, and another with NE-trending sinistral strike-slip structures.

The Rio Vacacaí Terrain (Fragoso-Cesar 1991) presents Tonian and Cryogenian rocks of basic/ultrabasic composition, low grade volcanosedimentary metamorphics and TTG complexes. Its occurrences are located to the northwest of the Camaquã Basin and are limited in the south by the WNW/ESE, dextral and steeply dipping Ibaré Shear Zone (Fragoso-Cesar 1991).

The brittle tectonic events that formed and deformed the Camaquã Basin activated these previous structures, most notably the main deformational event that activated the NNE to NE-trending structures of the Rio Vacacaí Terrane and the Dom Feliciano Belt (Fig 2) as left-lateral steeply dipping faults. This main event obliterated most (but not all) of the previous brittle deformational structures.

The composing units of the Camaquã Supergroup occur in structural blocks limited by steeply dipping faults and, with the exception of the Guaritas Group, generally present dips between $16^{\circ}$ and $60^{\circ}$, with varying but mainly NE-SW strikes (Figs 3, 4, 5 and 6). Locally, at the vicinity of major faults such as the Andradas and Minas do Camaquã fault zones, the beds have higher dips, reaching $90^{\circ}$. Despite the descriptions of previous authors (e.g. Ribeiro et al. 1966), this intense deformation near the fault zones also affects the Guaritas Group and is clearly seen near the Minas do Camaquã Fault Zone, south of the Camaquã River, where a thick succession of fluvial and eolian deposits of the Guaritas Group occurs as near vertical beds due to fault dragging. Open folds with north-south axes affect the whole succession, being more evident in areas where the fault-induced tilting is less prominent (Figs 5 and 6).

The map distribution of the composing units of the Camaquã Supergroup is strongly controlled by later tectonic events, and the basin itself is divided into three sub-basins (Fig 3), called eastern, central and western Camaquã sub-basins, separated by basement highlands (Caçapava do Sul and Serra das Encantadas highlands). These two basement highs are limited by steeply dipping NNE-SSW-trending faults or fault zones. This NNE-SSW system is the Irapuá Fault System (Ribeiro et al. 1966), and includes faults within the sub-basins, some of them with displacements big enough to juxtapose successions of different groups. A common feature in the NNE-SSW faults is the inversion of apparent vertical displacement along their strike, caused by successive reactivation and strike-slip movement cutting tilted blocks. Another important set of brittle structures is composed of steeply dipping faults with approximately WNW-ESE trends, called Cerro da Vigia Fault System by Ribeiro et al. (1966). These structures rarely juxtapose different units of the Camaquã Supergroup, but some of the fault zones are responsible for intense deformation, marked by verticalization of beds and abundant minor faults. Evidence of successive reactivation is also present in this system.

Both fault systems are related to anisotropy directions of the basement of the Camaquã Basin (Fig. 2). The NE-SW to NNE-SSW fault system reactivates metamorphic Neoproterozoic and Paleoproterozoic schistosities found in the Dom Feliciano Belt and in the northern and eastern portions of the Rio Vacacaí Terrane. The faults with WNW-ESE trends are controlled by metamorphic schistosity and shear zones at the southern border 


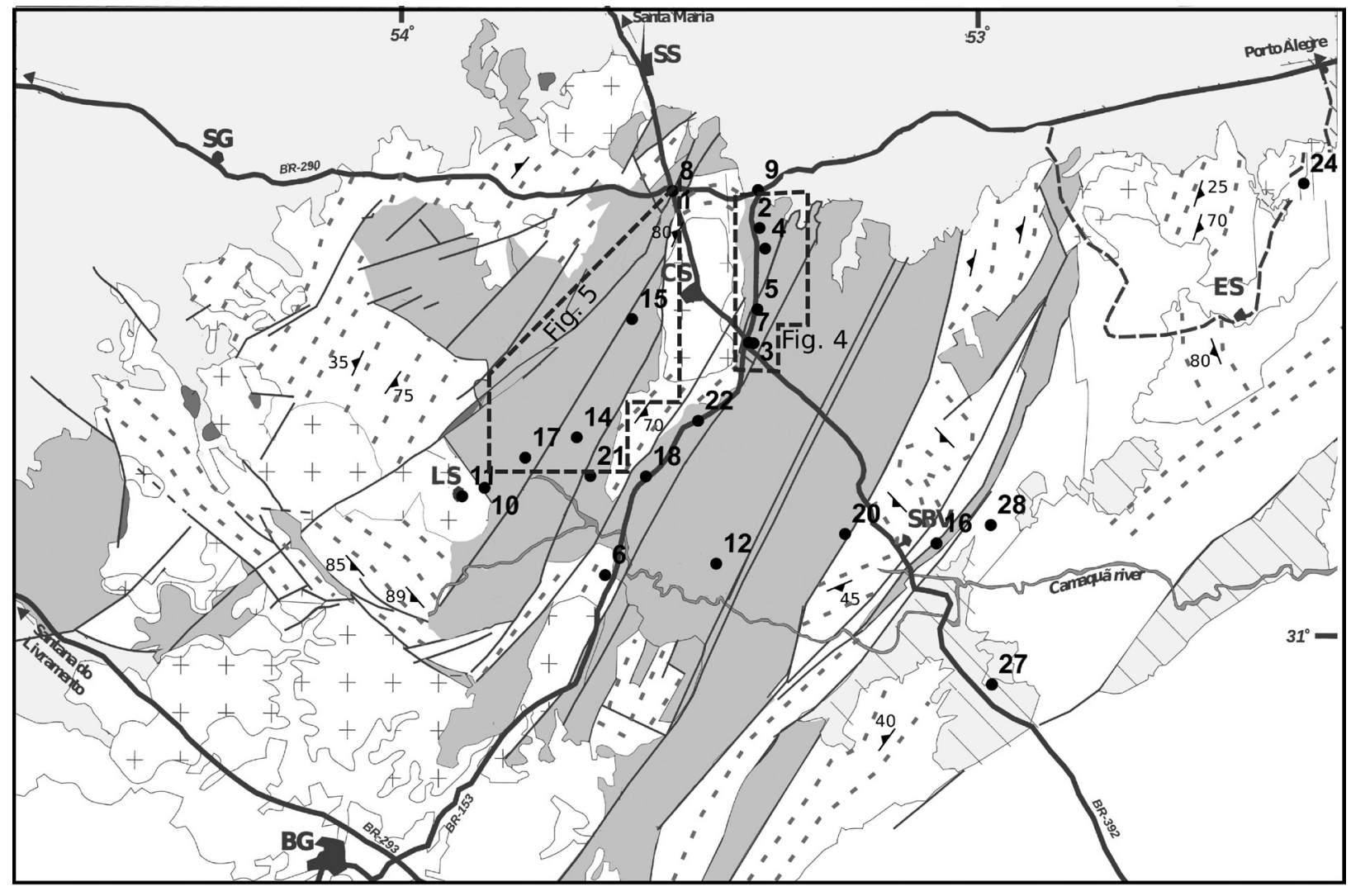

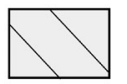

Triassic successions

Paleozoic successions

Camaquã Supergroup

35 Bedding strike and dip

\section{++ Granites}

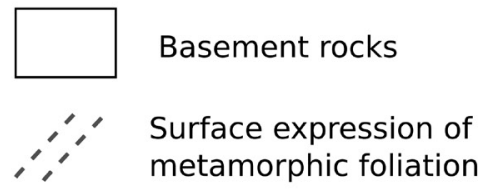

-10 Analyzed outcrop

Figure 2: Location of analyzed outcrops of the Camaquã Basin region and map distribution of the main structures of its basement.

of the Rio Vacacaí Terrane, near its contact with the Valentines Block (northern Rio de La Plata Craton).

The steep dips and the great lateral continuity of the faults of both systems, which are typically more than $30 \mathrm{~km}$ long, suggest the predominance of strike-slip displacement. Despite that, the provenance analysis of deposits of alluvial fans and fan-deltas in various stratigraphic levels (Fambrini et al. 1992, Fambrini 1998, 2003, Fragoso-Cesar et al. 2000, 2001, Almeida 2001, 2005, Janikian et al. 2003, 2005, Janikian 2004) shows that strikeslip displacement between the deposits and their sources is not greater than a few hundred meters. This evidence suggests that strike-slip deformation was not related to the basin-forming events, but only to post-depositional activation of faults with small individual displacements.

Detailed geological mapping of selected areas of the basin reveals that the prevailing deformational style is the same in all units of the Camaquã Super- 


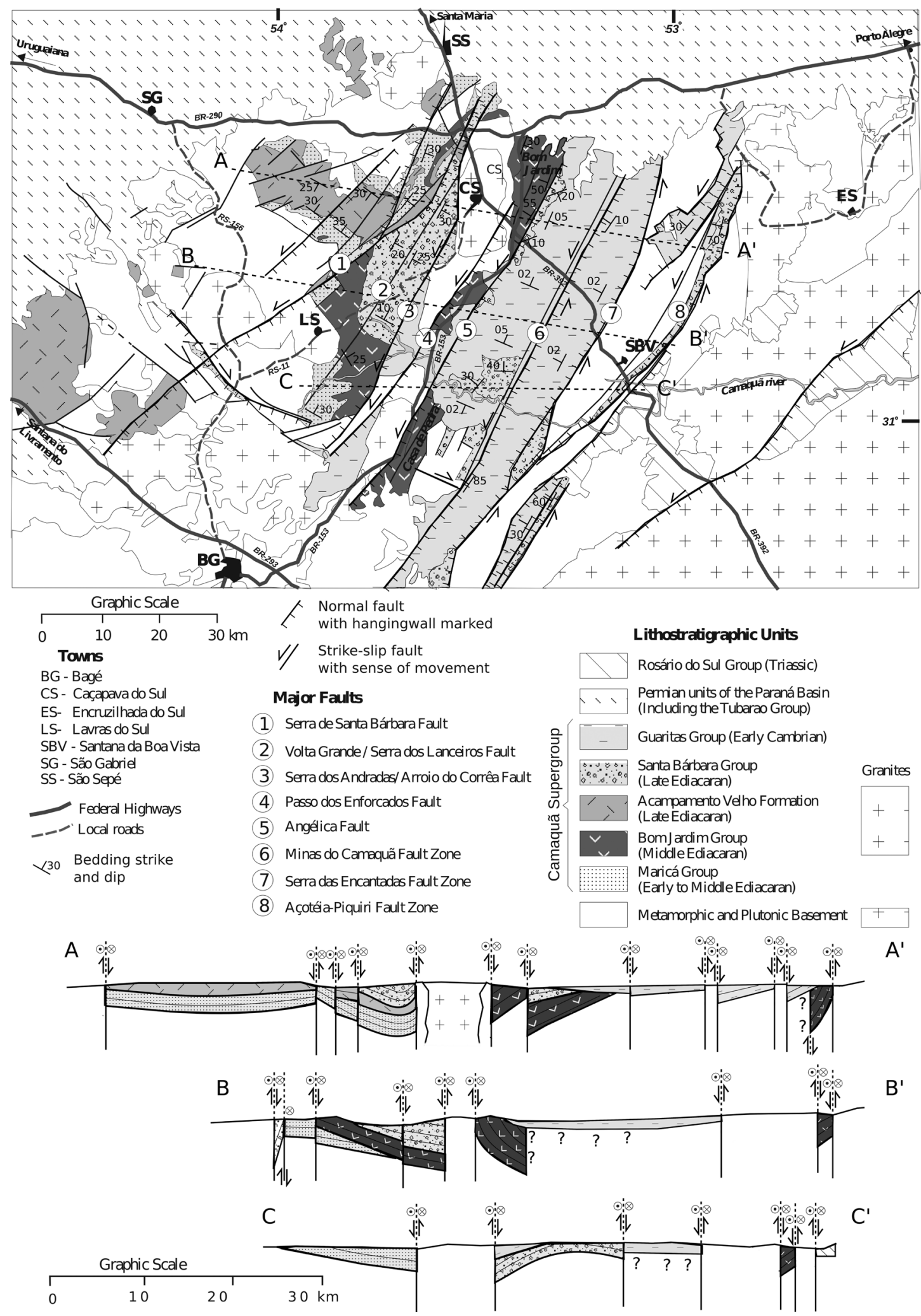

Figure 3: Geological sketch map and sections of the Camaquã Basin and nearby areas. Modified from Fragoso-Cesar et al. (2000). See location on Figure 1. 

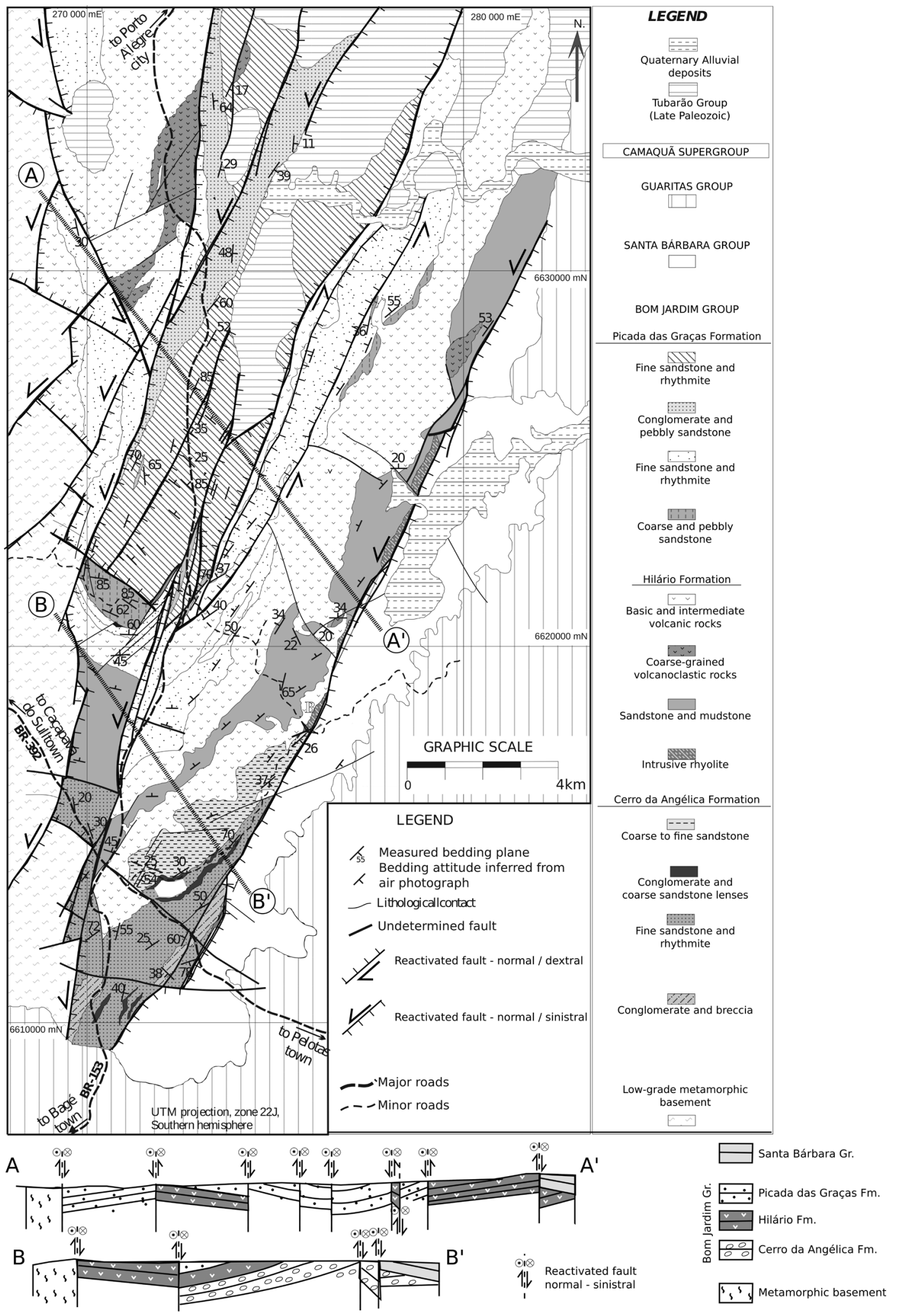

Figure 4: Geological sketch map and sections of the type area of the Bom Jardim Group and nearby areas. Modified from Janikian et al. (2003). For location see Figure 2. 
Legend

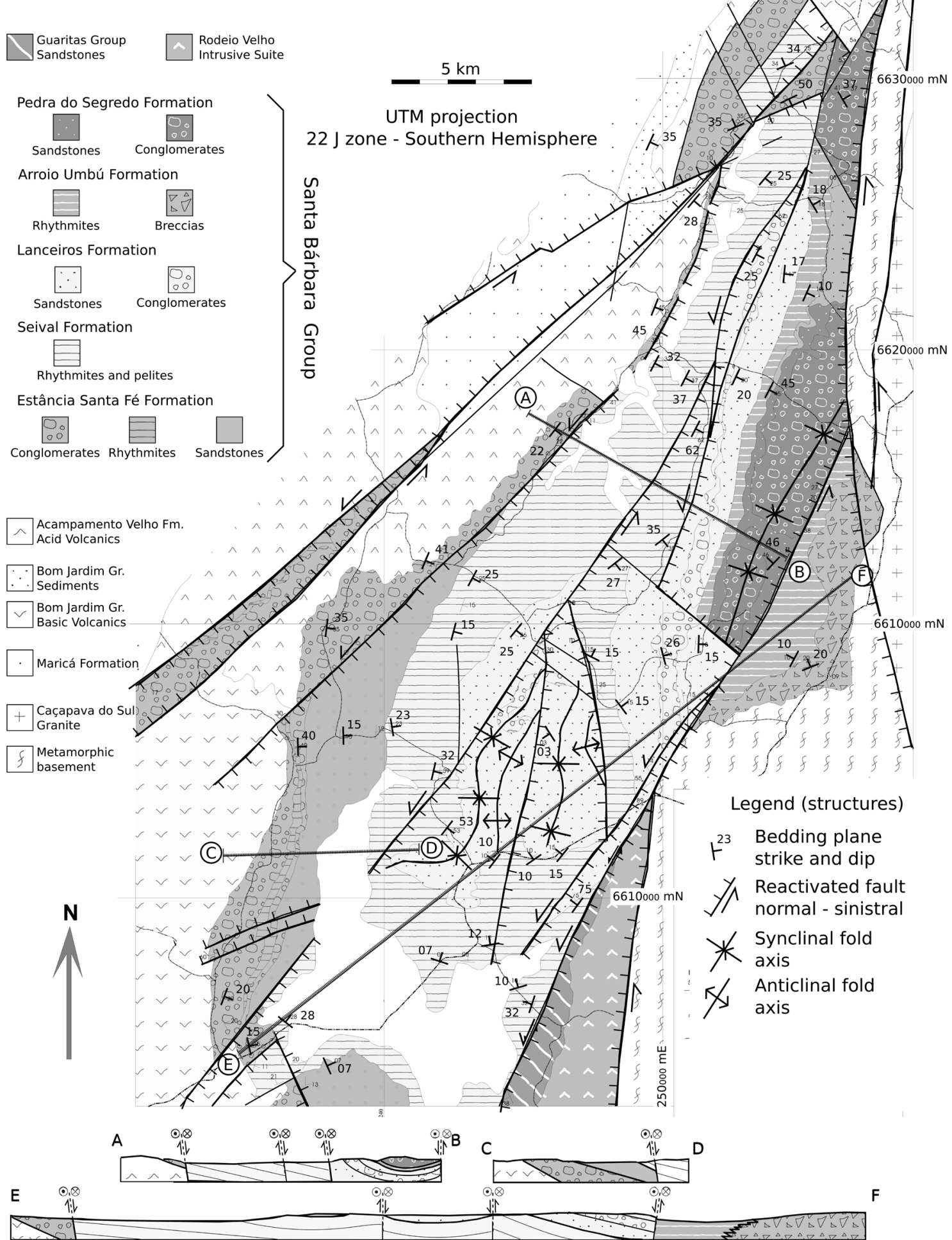

Figure 5: Geological sketch map and sections of the type area of the Santa Bárbara Group and nearby areas. Modified from Almeida (2005). For localization, see Figure 2. 

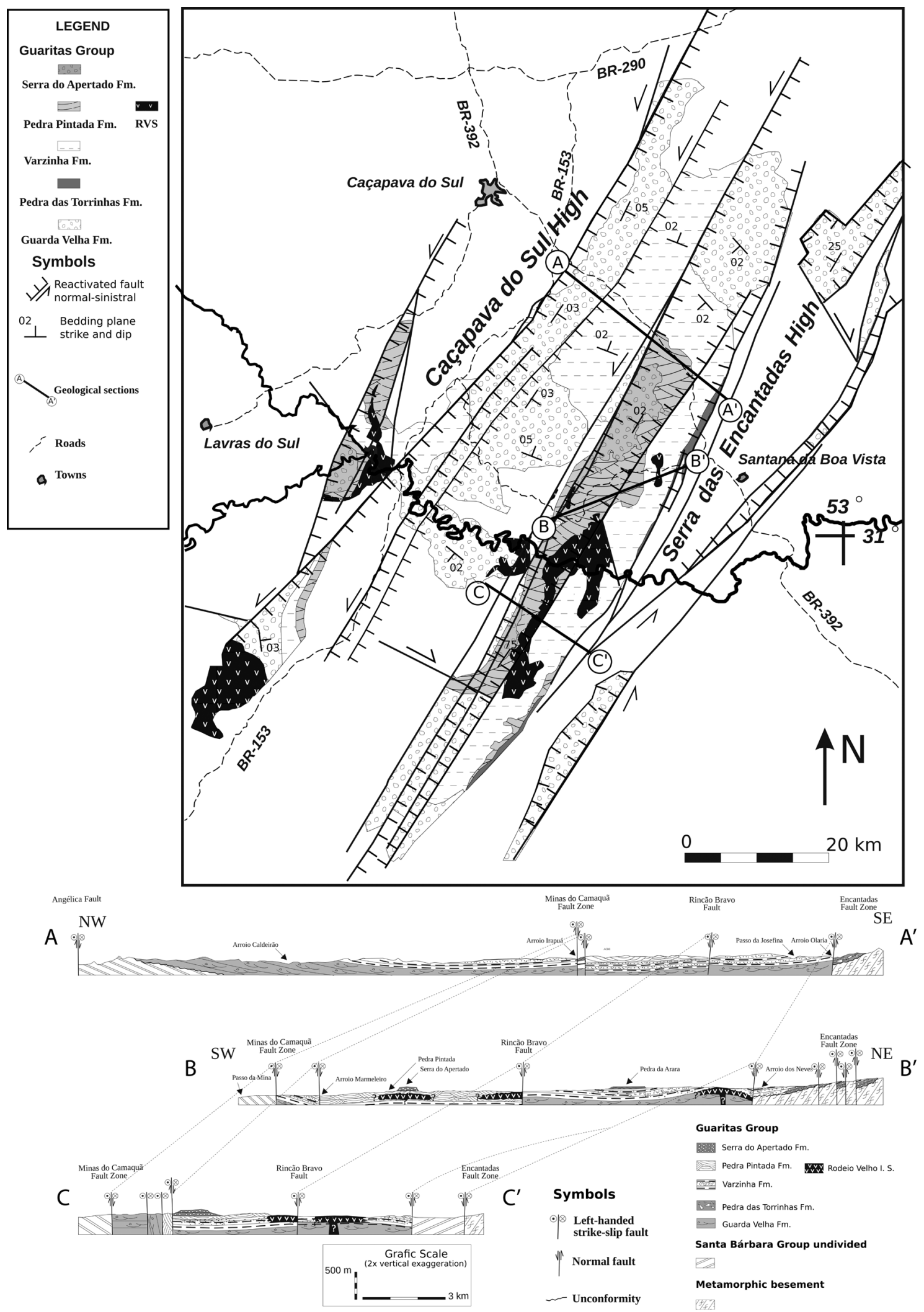

Figure 6: Geological sketch map and sections of the Guaritas Group. Modified from Almeida (2005). 
group (Figs 3, 4, 5 and 6): steeply dipping normal, oblique and strike-slip brittle faults, defined by discrete planes, commonly presenting striations and locally constituting fault bundles, sometimes related to drag folds, verticalization of bedding planes and rare tectonic breccias. The resulting movement observed on the major NE-trending faults is always a composition of early NE-SW extension and later leftlateral activation, reflecting the main tectonic events (Fig. 5). Despite that, the density of faults is greater in the lower stratigraphic units (Maricá and Bom Jardim Groups and Acampamento Velho Formation), and the bedding planes tend to be steeper in those older successions, as clearly seen in the type-area of the Bom Jardim Group (Fig. 4). This fact is interpreted as the result of the recurrence of tectonic events along the depositional history of the Camaquã Supergroup, which are possibly related to the origin of angular unconformities. Reverse faults were observed only locally, without specific stratigraphic position. They are interpreted as the result of the same compressional events responsible for the main strike-slip faults.

\section{PALEOSTRESS FIELDS}

The paleostress inversion of brittle faults with slickenside fibers and striations from each major unit of the Camaquã Supergroup, as well as Paleozoic and Mesozoic units that crop out in the same region, led to the recognition of five distinct stress fields (Table I), two of them interpreted as related to the basin-forming tectonics and the other three to later deformation. A sixth event is recognized regionally, but could not be identified in our dataset. The relative chronology of the events was established through stratigraphic control of fault families and, where possible, cross-cutting relationships of striations (Fig. 7). Age constraints are based on available geochronological data for the Bom Jardim Group and the Acampamento Velho Formation (Janikian et al. 2008, 2011), as well as for the Rodeio Velho Intrusive Suite (Almeida et al. 2009).

Although the paleostress analysis was carried out from the younger units to the older ones, the main identified tectonic events are described below in order of occurrence, to clarify their chronology.

\section{Middle to Late Ediacaran extension}

The Bom Jardim Group is the older unit of the Camaquã Basin that clearly shows the influence of active basin-border faults during its deposition (Janikian 2004). Therefore, the Maricá Group was not considered in the present work given its scarcity of outcrops showing faults and the uncertanties regarding its role in the tectonic evolution of the basin. The sedimentation age of the Bom Jardim Group has been determined through geochronological analysis of several stratigraphic levels of volcanoclastic and volcanic rocks (Janikian et al. 2008), ranging from 600 to $580 \mathrm{Ma}$. This unit is affected by a set of steeply

\begin{tabular}{|c|c|c|c|c|c|}
\hline & 600 to $545 \mathrm{Ma}$ & $545 \mathrm{Ma}$ & $535 \mathrm{Ma}$ & $530 \mathrm{Ma} ?$ & Cretaceous \\
\hline Units affected & ENE $\sigma 3$ & NNE $\sigma 1$ & NW $\sigma 3$ & NW $\sigma 1$ & NE $\sigma 3$ \\
\hline \multicolumn{6}{|l|}{ Rosário do Sul Group (Triassic) } \\
\hline \multicolumn{6}{|l|}{ Itararé Group and Rio Bonito Fm. (Permian) } \\
\hline \multicolumn{6}{|c|}{ Rodeio Velho Intrusives (Cambrian) } \\
\hline Guaritas Group (Cambrian) & & & Basin-forming & & \\
\hline Santa Bárbara Group (Late Ediacaran) & Basin-forming & & & & \\
\hline \multicolumn{6}{|l|}{ Acampamento Velho Fm. (Ediacaran) } \\
\hline Bom Jardim Group (Ediacaran) & Basin-forming & & & & \\
\hline \multicolumn{6}{|l|}{ Lavras do Sul and Caçapava granites } \\
\hline Maricá Group & & & & & \\
\hline
\end{tabular}

Figure 7: Chronology of tectonic events sorted by stratigraphic criteria and cross-cutting relationships of slickensided striations on the same plane. Dark gray rectangles indicate proved stratigraphic occurrence of each event, while light gray rectangles indicate supposed occurrence. 
dipping brittle faults formed by a stress field with vertical $\sigma 1$ and horizontal $\sigma 3$ in the NE quadrant, characterizing an ENE-WSW to NESW extension (Fig. 8). Although faults compatible with a NE-SW extension are found in all studied units, affecting even Triassic successions (see below), the structures affecting the Bom Jardim Group present much higher density of occurrence than those found in higher stratigraphic levels, which are clearly post-Triassic. Where this later (possibly Cretaceous, see below) extension affects the Bom Jardim and Santa Bárbara groups, it reactivates strike-slip faults.

Feeder dikes of the Bom Jardim Group volcanic rocks are oriented mainly around NNW (Fig 8), suggesting that the ENE-WSW extensional paleostress field is related to the basin-forming tectonics during the deposition of the Bom Jardim Group. Paleogeographic reconstructions based on stratigraphic analysis and detailed mapping (Janikian 2001, 2004, Janikian et al. 2003, 2005) reveal a north-south oriented basin axis for the Bom Jardim Group, which is compatible with the interpreted paleostress field.

The Late Ediacaran basin-forming tectonics is recorded in the Camaquã Basin as the Acampamento Velho Formation (acid volcanic and pyroclastic rocks) and the post-volcanic Santa Bárbara Group. The Acampamento Velho Formation overlies the Bom Jardim Group and shows crystallization ages of $573 \pm 18$ (U-Pb SHRIMP - Chemale Jr. 2002) and $574 \pm 7$ (U-Pb zircon age - Janikian et al. 2005). Sommer et al. (2005) obtained an age of $549 \pm 3$ $\mathrm{Ma}$ (U-Pb SHRIMP) in samples of acid intrusive rock that was interpreted as correlated to the Acampamento Velho Formation.

The Santa Bárbara Group, which is here considered as Late Ediacaran, overlies the Acampamento Velho Formation and is overlain, in angular unconformity, by the Early Cambrian Guaritas Group. The present analysis could not identify any compressional event related to the angular unconformity between Santa Bárbara and Bom Jardim Groups, and this is interpreted as an evidence that this unconformity resulted from local uplifting due to the continuity of the extensional tectonics.

Dikes related to the Acampamento Velho extrusive rocks show ENE-WSW average directions (Fig 8), suggesting a NNW-SSE minimum horizontal stress axis at approximately $570 \mathrm{Ma}$, but no consistent set of faults with striations compatible with this stress field was obtained in our study. Synsedimentary normal faults with NNW-SSE to NESW strikes are found in the overlying Santa Bárbara Group (Fragoso-Cesar et al. 2001, Fambrini et al. 2001, Fambrini and Fragoso-Cesar 2006), and the paleostress inversion of these structures gives an extensional stress field with E-W $\sigma 3$, which is not very different from the paleostress field interpreted as related to the basin subsidence during the deposition of the Bom Jardim Group. Despite that, both events are separated by an angular unconformity (between the Bom Jardim and Santa Bárbara groups) and are recorded in the Bom Jardim Group, where crosscutting relationships of striations can be attributed to this succession of events. A set of meso-scale normal faults affecting the Santa Bárbara Group and older units also gives a paleostress field with ENE-WSW $\sigma 3$ (Fig. 4), corroborating the interpretation of a Late Ediacaran extensional event.

Paleogeographic reconstructions based on depositional systems mapping, as well as paleocurrent and provenance analyses (Fambrini et al. 2005, Fragoso-Cesar et al. 2000, 2001, Almeida 2001, 2005, Janikian 2001, 2004, Janikian et al. 2003, 2005, Fambrini 2003), suggest the presence of a roughly N-S trending basin-border normal fault during the deposition of the Santa Bárbara Group, thus corroborating the interpretation of an ENEWSW extension in the Late Ediacaran.

Given the uncertainties regarding the actual strike of the original main faults during sedimentation, it is purely speculative to discuss weather there was a transtensional (oblique) component 


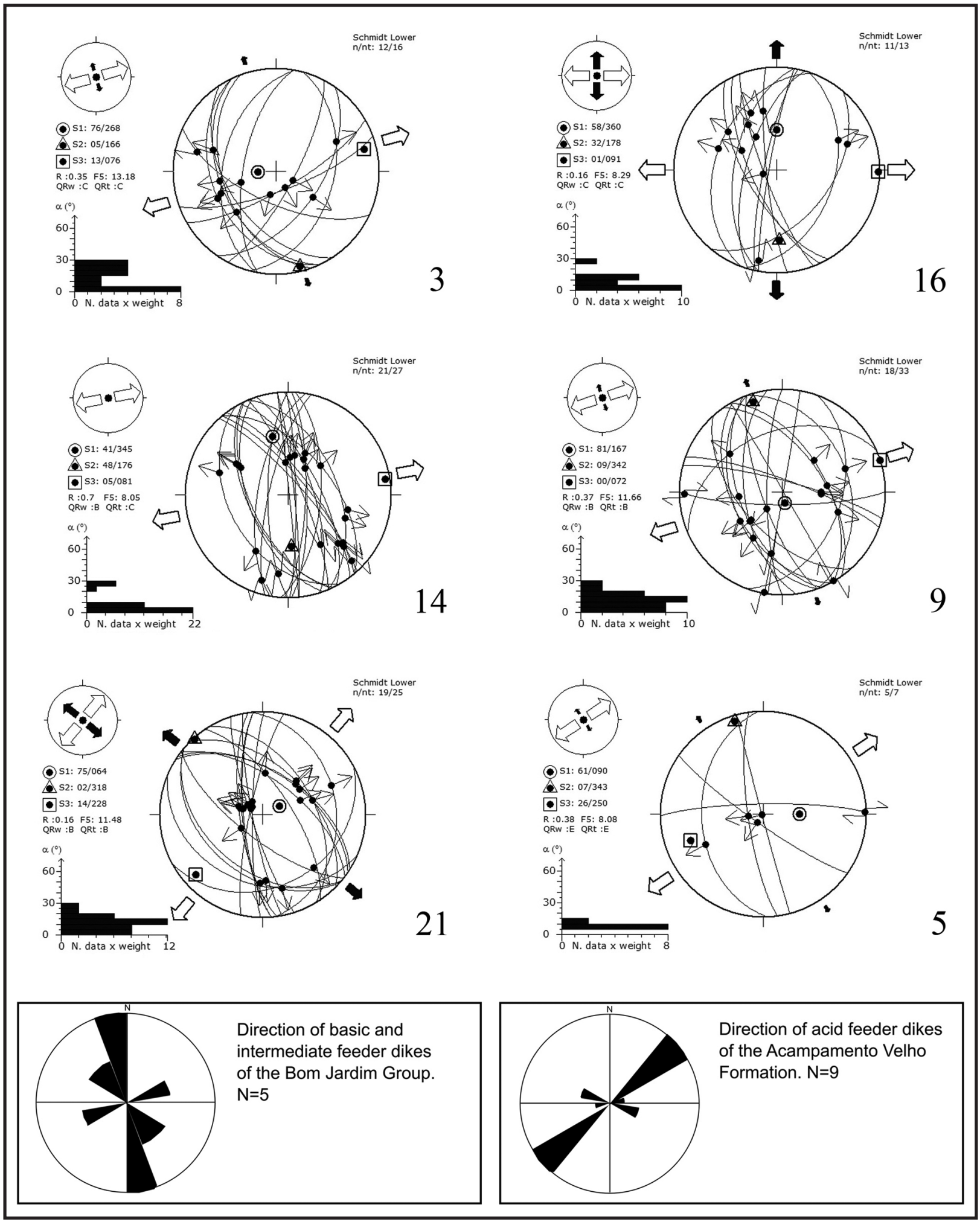

Figure 8: Characteristic examples of stereographic projections corresponding to data measurements of the first and second recognized paleostress fields (ENE extension), Schimidt projection, lower hemisphere. Fault planes are great circles; slickensided lineations are small centrifugal traces (normal faults) or double traces (strike-slip faults). 
in their movement or not. The vertical nature of $\sigma_{1}$ can be emphasize, which contradicts models considering a strike-slip origin for the basin.

\section{Late Ediacaran - Early Cambrian strike-slip faulting}

A major angular unconformity separates the Guaritas Group (Early Cambrian) from the older units of the Camaquã Supergroup. This unconformity is related to a strike-slip faulting event that generated ENE-WSW to WNW-ESE left-slip and NNE-SSW to NNW-SSE right-slip faults affecting all the units of the Camaquã Supergroup but the Guaritas Group. Paleostress field inversion of this fault group gives a NE-SW to NNE-SSW oriented horizontal $\sigma 1$ and a near vertical $\sigma 2$ (Fig. 9). The stratigraphic position of this event suggests that it occurred near the Precambrian-Cambrian boundary.

\section{Early Cambrian extension}

The Guaritas Group and the Rodeio Velho Intrusive Suite (mainly basic to intermediate shallow sills) record the youngest basin-forming tectonic events of the Camaquã Supergroup, which generated NE-SW to NNW-SSE-trending normal faults. The paleostress field obtained for these faults gives a WNW-ESE to NW-SE $\sigma_{3}$, characterizing an event of NW-SE extension (Fig. 10). Faults attributed to this event are not found in younger units. The presence of alluvial fan deposits in the Guaritas Group next to the eastern NNE-SSW-striking basin-border fault reveals that this fault was active during the deposition of the unit (e.g. Marconato et al. 2009). Therefore, this event can be considered as syn-depositional to the Early Cambrian succession, thus postdating the first strike-slip fault event and predating the second one. Intense extensional deformation of the Guaritas Group suggests ongoing extension during sedimentation. This deformation includes open fault-drag folds with N-S axis.
The depositional age of the Guaritas Group is constrained by dating of the Rodeio Velho Intrusive Suite (Almeida et al. 2009) obtained in a sample of a shallow sill that caused fluidization of then unconsolidated host sediment of Guaritas Group. Thus, the crystallization age obtained for the Rodeio Velho Intrusive Suite $(535.2 \pm 1.1 \mathrm{Ma})$ by Almeida et al. (2009) is interpreted to be very close to the sedimentation age of the Guaritas Group. As the second NW-SE extensional event is considered to be coeval to the deposition of the Guaritas Group and related to the subsidence tectonics, this age determination also constrains the tectonic event.

\section{Post-Early Cambrian strike-slip faulting}

The main post-depositional deformational event that affected the Camaquã Supergroup is characterized by intense strike-slip faulting, mainly leftslip NE-SW to NNW-SSE faults and right-slip ENE-WSW to WNW-ESE faults, including the major faults that juxtapose different units of the Camaquã Supergroup and its basement. This fault group affects the Guaritas Group and the Rodeio Velho Intrusive Suite, but has not been found in younger Phanerozoic deposits in the region and hence was generated after Early Cambrian and before Early Permian. Paleostress field inversion of this fault population gives a NW-SE oriented horizontal $\sigma_{1}$ and a near vertical $\sigma_{2}$ (Fig. 11). Fault-drag folds are found near the major faults. Cross-cutting relationships of striations corroborate the interpretation of this set of structures being younger than those generated by a NE-SW compression.

The copper mineralization found in deposits of the Santa Bárbara Group in the Minas do Camaquã region may be related to this tectonic event since the mineralization is associated to WNW-ESE-trending faults that behaved as extensional structures during this event, which is compatible with the T-fractures of the conjugate system (Santos et al. in press). 

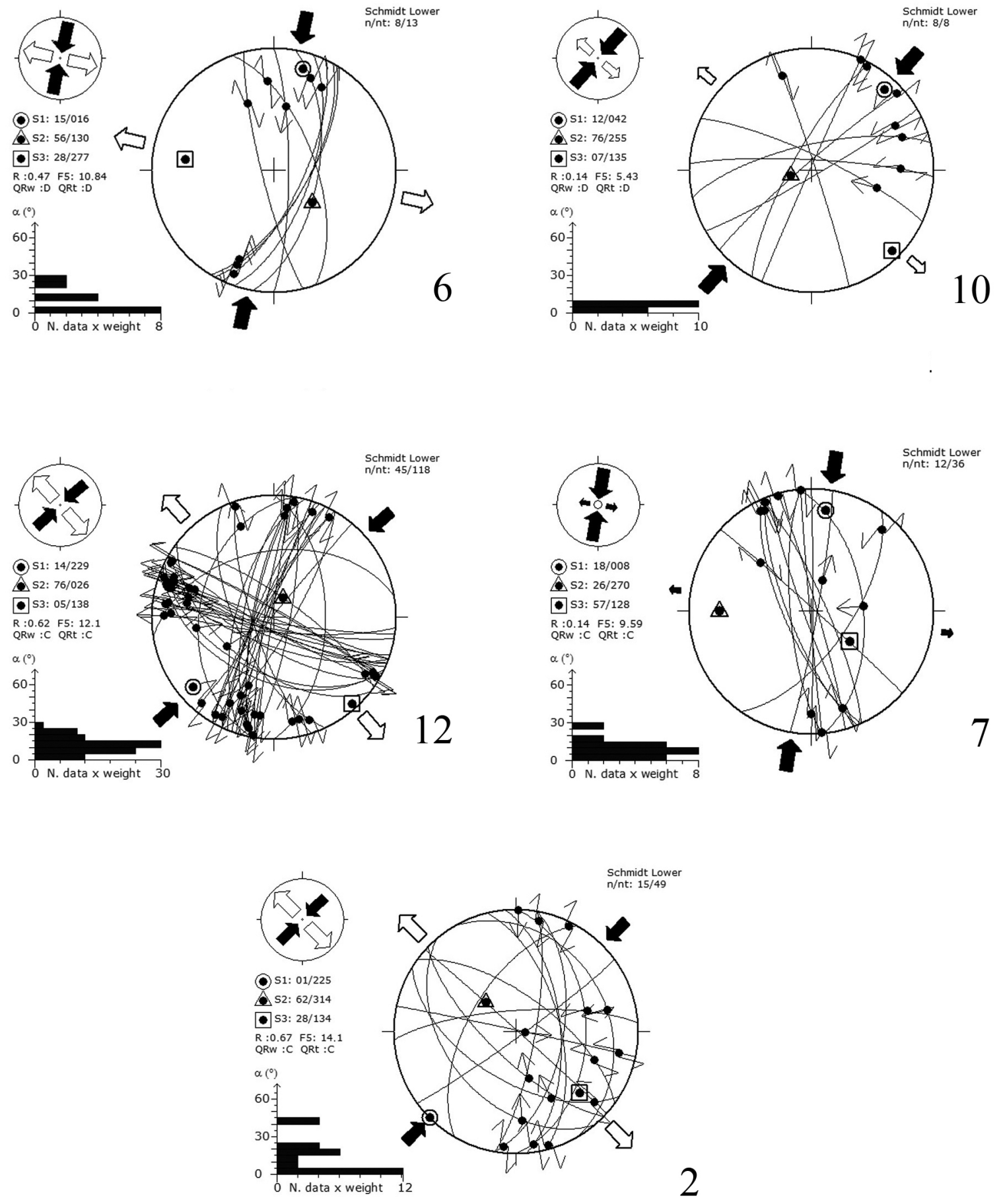

Figure 9: Characteristic examples of stereographic projections corresponding to data measurements of the second recognized tectonic event (NE compression), Schimidt projection, lower hemisphere. Fault planes are great circles; slickenside lineations are small centrifugal traces (normal faults), centripetal traces (reverse faults) or double traces (strike-slip faults). 

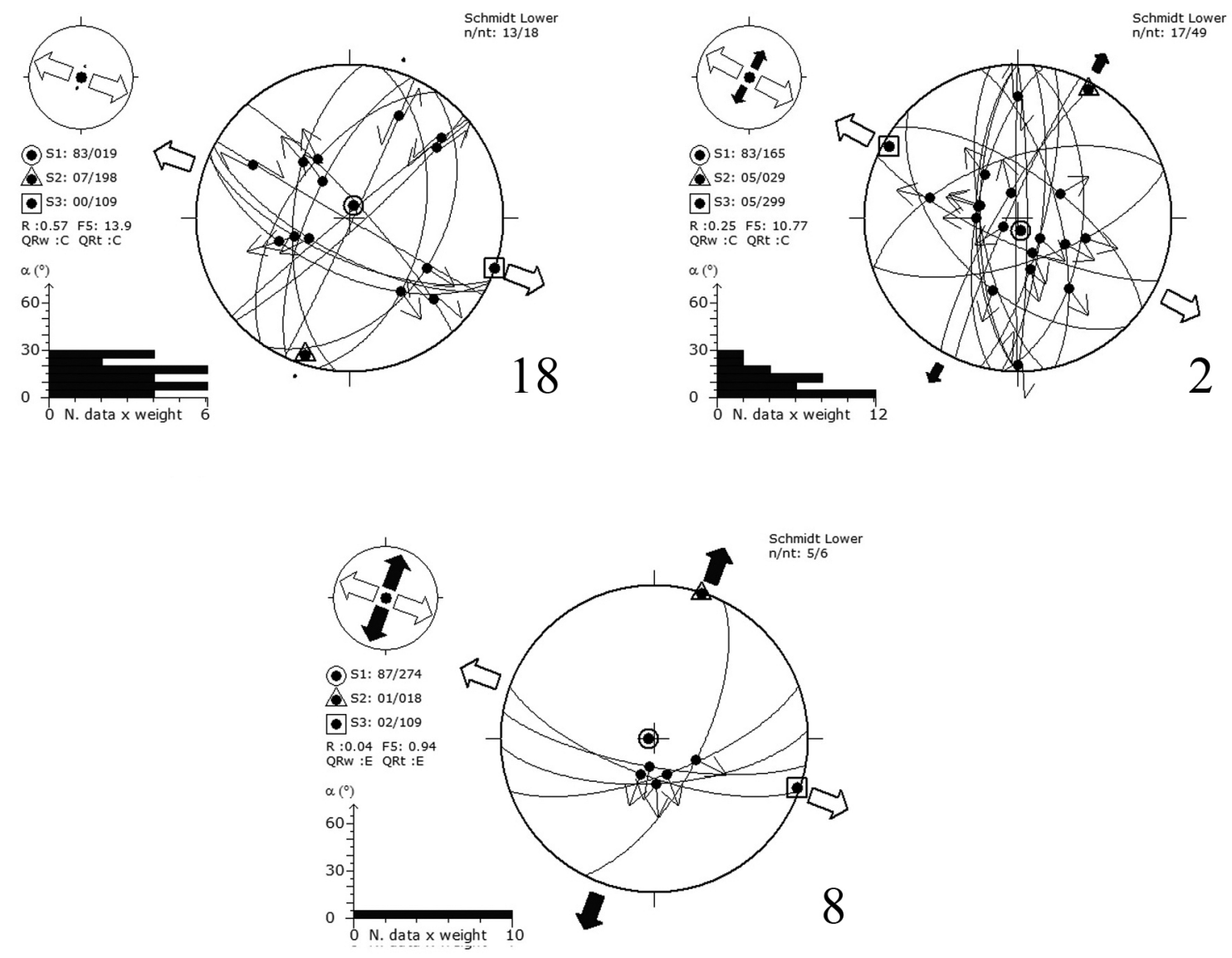

Figure 10: Characteristic examples of stereographic projections corresponding to data measurements of the third recognized tectonic event (NW extension), Schimidt projection, lower hemisphere. Fault planes are great circles; slickenside lineations are small centrifugal traces (normal faults) or double traces (strike-slip faults).

\section{Post-Early Triassic strike-slip faulting}

This deformation event is characterized by strikeslip faulting and affected sedimentary successions of the Tubarão Group (Permian), as well as the Sanga do Cabral Formation of the Rosário do Sul Group (Tomba 2006), which are considered to be of Early Triassic Age (Zerfass et al. 2003, 2004, 2005), in isolated occurrences directly above the Precambrian basement. We do not have enough data to obtain a consistent paleostress field for this event. Data presented by Tomba (2006) suggest a paleostress field with NE-SW oriented horizontal $\sigma 1$ and a near vertical $\sigma_{2}$. This paleostress orientation is interpreted as a repetition of the Ediacaran-Cambrian strike-slip event, though it was not as intense as the first one.

\section{Cretaceous extension}

The youngest event of brittle faulting observed in the studied successions is characterized by normal faults with average NW-SE strikes, as well as related oblique faults, formed by a stress field with near vertical $\sigma_{1}$ and NE-SW oriented horizontal $\sigma_{3}$ (Fig. 12). These structures affect all the units of the Camaquã Supergroup, the Tubarão Group 

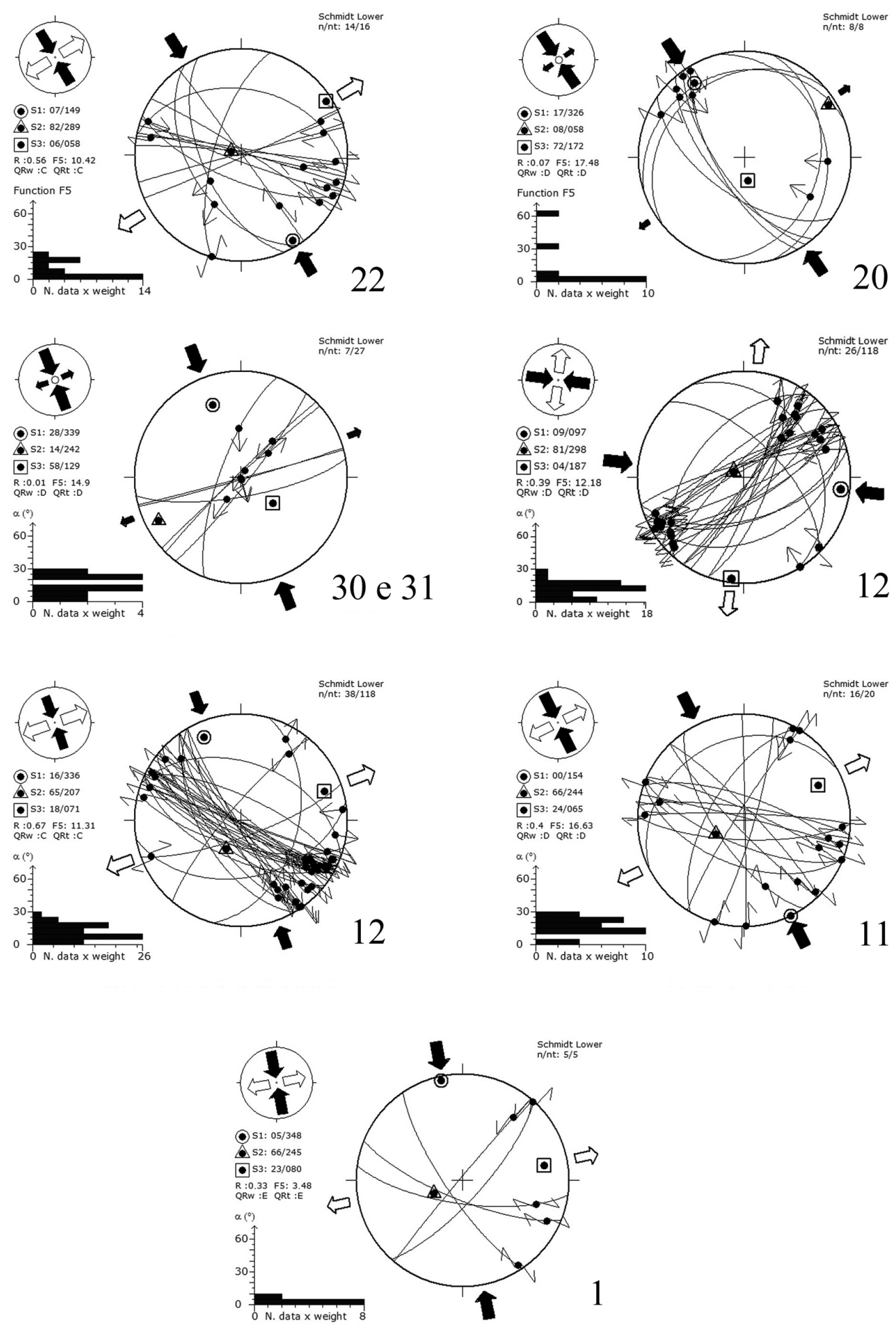

Figure 11: Characteristic examples of stereographic projections corresponding to data measurements of the fourth recognized tectonic event (NW compression), Schimidt projection, lower hemisphere. Fault planes are great circles; slickenside lineations are small centrifugal traces (normal faults) or double traces (strike-slip faults). 
(Permian) and the whole Rosário do Sul Group (Triassic), characterizing a post-Triassic event. The distinction of this event from the Middle to Late Ediacaran event of similar paleostress field is often difficult. Nevertheless, some outcrops of the older units show mainly oblique faults, which are most likely reactivated strike-slip faults of the compressional events, later submitted to the Cretaceous extensional field.

Two Cretaceous magmatic events may be related to this extensional event: the vast Early Cretaceous basic volcanism of the Serra Geral Formation whose feeder dikes show, in the region, directions compatible with a NE-SW extension, and the Late Cretaceous alkaline dikes that occur in the studied area (Ribeiro and Teixeira 1970) and also have compatible directions.

\section{CASTRO BASIN}

The Castro Basin is filled by feldspathic sandstones, siltones and conglomerates, as well as acid volcanic rocks, disposed in a more than $3,000 \mathrm{~m}$ thick succession, with more than $800 \mathrm{~km}^{2}$ of exposed area (Moro et al. 1993, 1994, Moro 2003). Controversy regarding the tectonic setting of its origin also exists for the Castro Basin, with concurring models of post-orogenic molasse basin (Trein and Fuck 1967) and transtentional strike-slip basin (Soares 1987, 1988).

The style and directions of the faults that affect the Castro Basin are the same as those of the structures that affect the Camaquã Basin. Steeply dipping faults with NE to NNE strikes are the main structures, presenting large normal displacements, including the basin-border fault, which is parallel to the NNE-trending metamorphic foliation of the basement. NW trending faults are also present, showing smaller displacements and frequently being intruded by basic dikes of Early Cretaceous age. The presence of alluvial fan deposits suggests active syn-sedimentary faulting at the basin borders.
PALEOSTRESS FIELDS

Previous paleostress data for the Castro Basin are restricted to less then 25 faults with striations grouped in a strike-slip event with $\mathrm{NE} \sigma_{1}$ and an extensional event with $\mathrm{NE} \sigma_{3}$ (Bonacim et al. 1994). Our data, although also very scarce, reveal a more complex structural evolution with mutually incompatible fault sets attributed to two different tectonic events:

- A NW compression activating NE trending faults with reverse and oblique left-lateral movement.

- A NNE extension, revealed by ENE to WNW striking normal and oblique faults.

Although there are no clear cross-cutting relations among striations of different events, the correlation of these paleostress fields with those interpreted for the Camaquã Basin suggests that the NW compression is correlatable to the main strikeslip deformation of the Camaquã Basin, possibly of Early Cambrian age. The NNE extension is very likely related to the Cretaceous magmatism, as basic dikes of this age intrude many of the NW structures.

\section{ITAJAÍ BASIN}

The Itajaí Basin contains more than 10,000 m of alluvial, deltaic and turbiditic successions (e.g. Rostirolla et al. 1992a, Fonseca et al. 2003, Basilici 2006) in an area of approximately $1,200 \mathrm{~km}^{2}$. Several authors consider this basin as a foreland basin of the Brasiliano Orogeny (e.g. Fragoso-Cesar et al. 1982a, b, Rostirolla and Soares 1992, Rostirolla et al. 1992a, b, 1999, Gresse et al. 1996, Basei et al. 2000), but there is no convincing evidence for the alleged syndepositional nature of the described thrust faults, nor for the supposed syn-orogenic context of the basin. The Itajaí Basin is coeval to part of the Camaquã Basin (Almeida et al. 2010), which suggests a common geotectonic setting for both basins.

The Itajaí Basin contains conglomerate, sandstone, sandstone-mudstone rhythmite and mudstone organized in four depositional sequences (Teixeira et al. 2004). Rhyolitic tuffs occur at some 


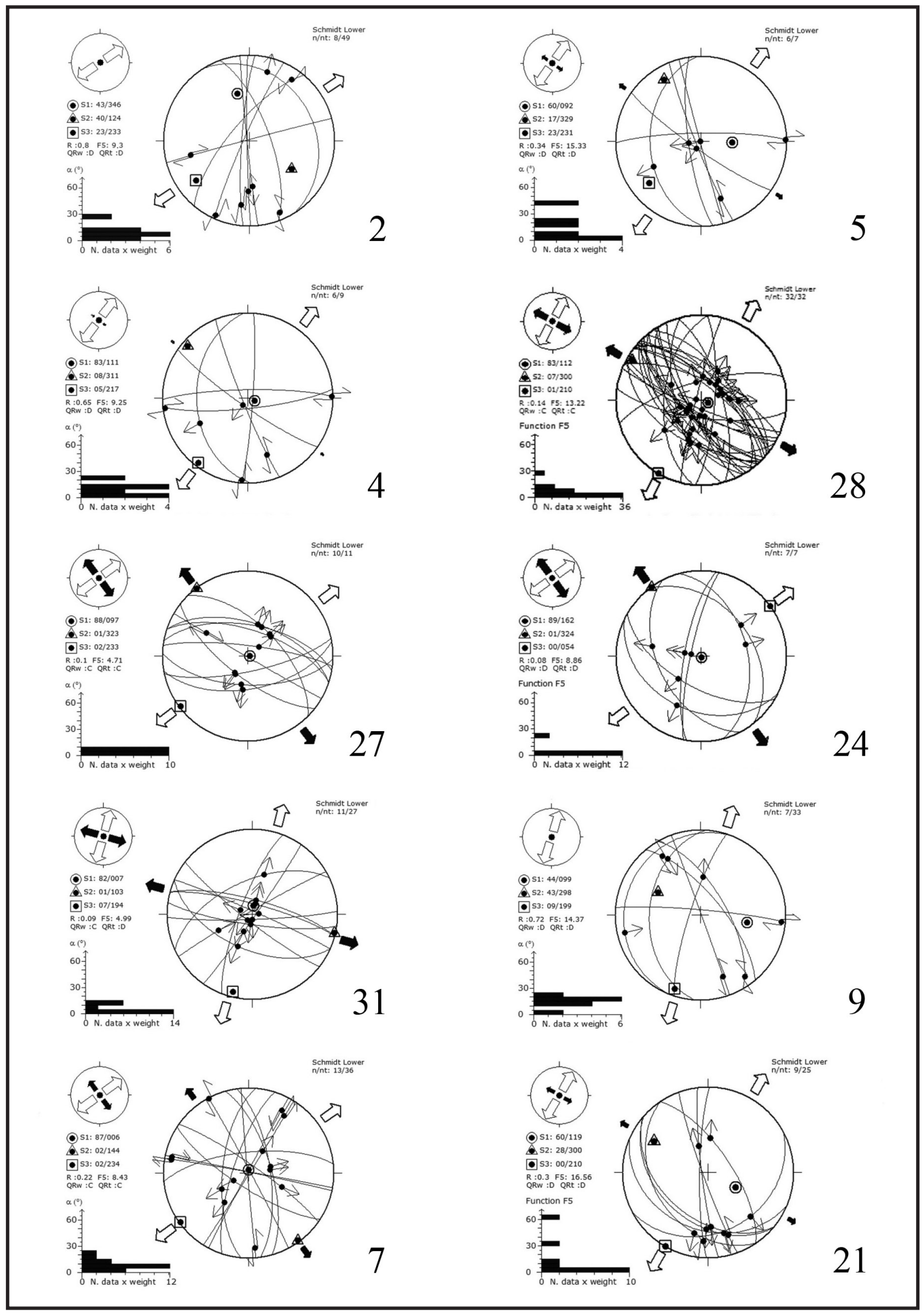

Figure 12: Characteristic examples of stereographic projections corresponding to data measurements of the last recognized tectonic event (NE extension), Schimidt projection, lower hemisphere. Fault planes are great circles; slickenside lineations are small centrifugal traces (normal faults) or double traces (strike-slip faults). 
stratigraphic levels and the basin is intruded by a granite stock (e.g. Basei et al. 1999, Cordani et al. 1999). The basin is bounded by a steeply dipping post-sedimentary reverse fault in its southeastern border, which activated ductile structures of the basement. Other structures are NE trending reverse to oblique faults and $\mathrm{E}-\mathrm{W}$ trending rightslip faults, reactivated to left-slip in a younger tectonic event (Rostirolla et al. 1992b), as well as open folds with NE axis.

\section{PALEOSTRESS FIELDS}

Rostirolla et al. (1992b) recognized two main deformational events in the Itajaí Basin: a first and more intense NW compression, forming the open folds and the NE to E-W trending right-lateral, oblique and reverse faults, and a younger NW compression, reactivating these same structures with the opposite movement.

Although the paleostress interpretation of Rostirolla et al. (1992b) was based on less then 30 data for the whole basin, the recognition of a main NW-SE compressional event is in accordance with the paleostress analysis of the Camaquã Basin, as is the recognition of a younger NE-SW compression. Considering that the main NW-SE compressional event is the same in all basins of the system, the deformation would be dominated by strike-slip faults in the NNE-SSW trending Camaquã and Castro basins, and by oblique to reverse faults in the ENE trending Itajaí Basin. Hence we interpret that the apparently conflicting structural styles of the Ediacaran successions of the system are the result of a single main deformation acting upon different previous anisotropies of basement rocks.

\section{DISCUSSION}

Most of the current tectonic models for eastern South America consider that the geological evolution of the region between $600 \mathrm{Ma}$ and 530 Ma records the last collisional episodes of the
Brasiliano Orogeny (e.g. Ribeiro and Fantinel 1978, Fragoso-Cesar 1991, Brito Neves et al. 1999, Basei et al. 2000, Campos Neto 2000, PedrosaSoares and Wieldmann-Leonardos 2000, Trouw et al. 2000, Heilbron and Machado 2003, Heilbron et al. 2004, Silva et al. 2005). In this context, the Ediacaran to Cambrian basins of the region have been considered as syn- to post-collisional, with their origin related either to supposed flexural loading during crustal thickening or to late-orogenic strike-slip deformation.

The here presented chronology of the deformational events that are preserved within the sedimentary and volcanic successions of the Camaquã Basin (Fig. 7), and its correlation to the Itajaí and Castro basins, point to an alternative interpretation previously deduced from provenance, paleocurrent and stratigraphic data: that of an extensional origin for this basin system.

The stratigraphic record of the deformational events of the Camaquã Basin reveals the recurrence of strike-slip and extensional episodes (Fig. 13) with no major thrust fault-generating compression. Thus, the paleostress fields do not support a syncollisional peripheral foreland basin model for the Camaquã Basin. Independent evidence suggests that the extensional events were responsible for the subsidence cycles, and that the strike-slip faulting events are related to younger deformation: (1) the oldest extensional event, with ENE-WSW to NE$\mathrm{SW} \sigma_{3}$, is found only in the lower stratigraphic levels and predates the first identified strike-slip event, as revealed by dikes feeding syn-depositional volcanism; (2) a similar extensional event, with E-W $\sigma 3$, was responsible for syn-sedimentary faulting in the Late Ediacaran Santa Bárbara Group; (3) the units generated during the last subsidence cycle of the basin, in the Early Cambrian, are not affected by the main compression and also record an extensional event prior to an event of strike-slip faulting, which shows a different orientation of stress axes from the previous. 
The occurrence of volcanic or pyroclastic successions in all three major basins of the system (the Camaquã, Itajaí and Castro basins) suggests that they were formed during a period of enhanced thermal gradient. This hypothesis is corroborated by the presence of several voluminous granitic intrusions coeval to the basins. Thus, it is not likely that the basins formed due to extensional collapse of thickened crust caused by the collision that had taken place more than $30 \mathrm{Ma}$ before. In the Camaquã Basin, the major intermediate to basic volcanism occurred in the time-span of the first extension, suggesting that this event was related to mantle upwelling.
The recurrence of extensional and strikeslip events suggests that a persistent tendency to extension, maybe due to a mantle thermal anomaly after the major continental collision of the Brasiliano-Pan-African Orogeny in the region, was repeatedly interrupted by compressional events, possibly the far-field response to the latest collisions at the margins of the still-forming Gondwana Plate.

The first identified compression, with NESW $\sigma_{1}$, occurred around the Ediacaran-Cambrian boundary and may be related to the deformational event recorded in the Gariep Belt of Southwestern Africa (Frimmel and Frank 1998). The second, postEarly Cambrian compressional event, with NW-SE

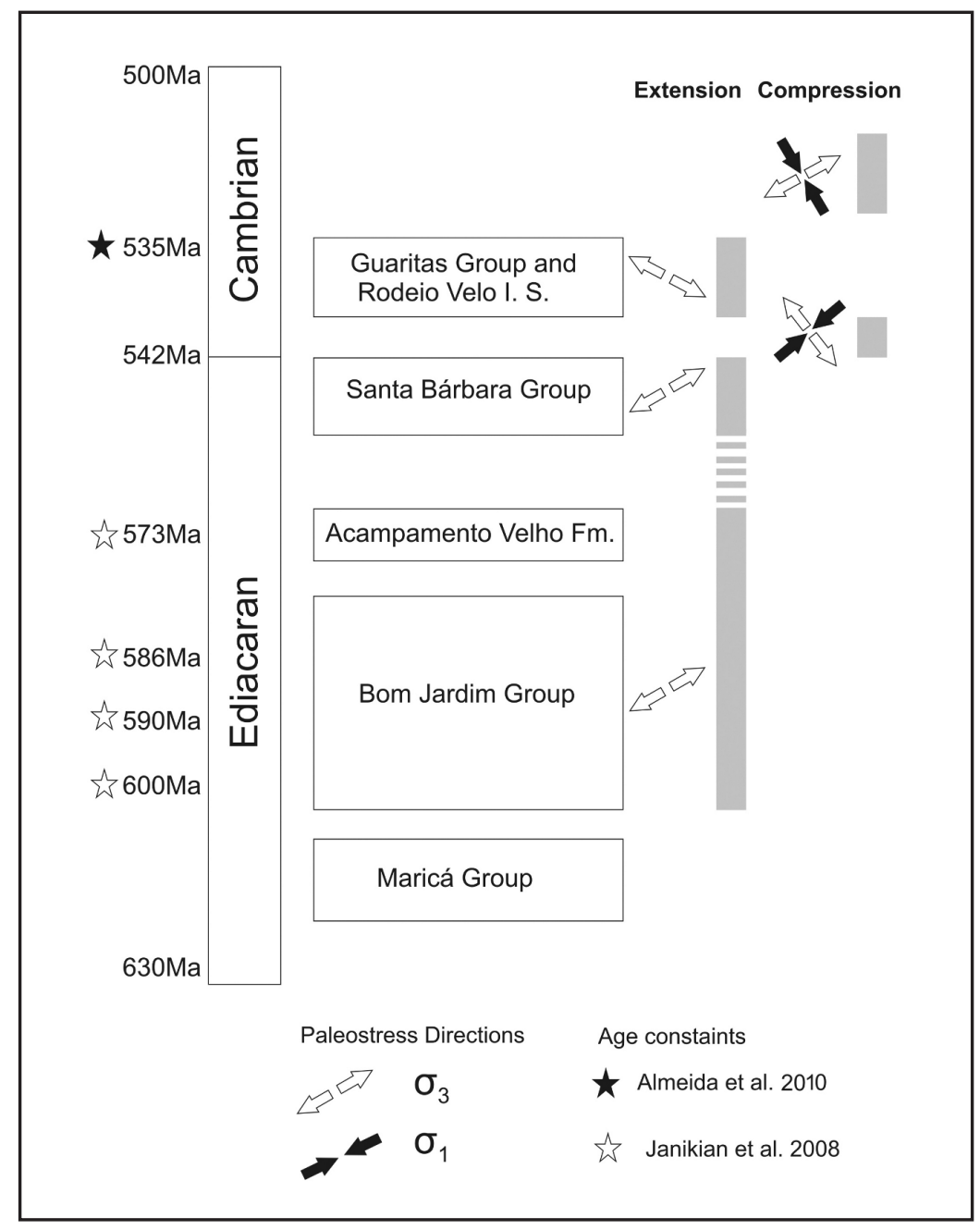

Figure 13: Summary of the paleostress evolution of the Camaquã Basin from Ediacaran to Cambrian. 
$\sigma_{1}$, is compatible with the last deformational events in the Paraguay Belt (Pimentel et al. 1996, Tohver et al. 2010), south of the Amazon Craton, and also with the final collision between eastern and western Gondwana around $530 \mathrm{Ma}$ (Meert 2001). Most of the post-collisional ductile strike-slip deformation that affects rocks of deeper crustal levels in the same region - the Southern Mantiqueira Province - may be related to the intense brittle strikeslip deformation of the basins due to these two compressional events at shallower crustal levels.

Our results suggest that the intense postorogenic strike-slip deformation recognized in the Neoproterozoic fold belts of Southeastern South America may be a response to later distal collisions and not the consequence of ongoing compression since the orogenic stage. The rapid paleostress changes identified on unmetamorphosed sedimentary and volcanic successions deposited after the main collision would be much more difficult to recognize in rocks of deeper crustal levels, where ductile deformation prevails, and there is no possible stratigraphic control enabling us to distinguish among superposed events.

\section{CONCLUSIONS}

The paleostress analysis of the Camaquã Supergroup and overlying Phanerozoic units revealed five main deformational events responsible for normal, strikeslip and oblique brittle faults found in the region. These events caused the reactivation of former basement structures, mainly with NNE-SSW and WNW-ESE strikes, in response to regional tectonic episodes from the Ediacaran to the Cretaceous.

The basin-forming tectonic events of the Camaquã Basin are mainly extensional, firstly with two phases of ENE-WSW to NE-SW $\sigma_{3}$ during the deposition of the Bom Jardim Group (600 Ma to 580 $\mathrm{Ma}$ ), the Acampamento Velho Formation ( $575 \mathrm{Ma}$ ) and the Santa Bárbara Group ( $550 \mathrm{Ma}$ to $545 \mathrm{Ma}$ ), and later with a NW-SE $\sigma_{3}$ during the formation of the upper units of the Camaquã Supergroup, including, the Guaritas Group ( $535 \mathrm{Ma}$ ) and the subvolcanic Rodeio Velho Intrusive Suite.

Besides these basin-forming tectonic events, three deformational tectonic events were recognized. The first occurred during the formation of the angular unconformity between the Santa Bárbara and Guaritas groups, thus near the PrecambrianCambrian boundary. This event is characterized by strike-slip and oblique faults formed during NE-SW compression.

The second, more intense, deformational event, is characterized by a NW-SE compression causing the major strike-slip and oblique faults that control the map distribution of the geological units of the Camaquã Basin and nearby areas. This event also affects the Guaritas Group and the Rodeio Velho Intrusive Suite, but not the Permian and Triassic units of the region, and thus occurred between $535 \mathrm{Ma}$ and the Permian. We suggest a relationship between this event and the compressional stress fields caused by the collision of Eastern and Western Gondwana, around $530 \mathrm{Ma}$, or the collision of the Amazon Plate to the northwest. This event caused the cessation of the subsidence in the Camaquã Basin.

A third deformational event caused a NE-SW extension generating normal and oblique faults found in all studied units, from the lower levels of the Camaquã Supergroup to the Triassic deposits. Late Cretaceous alkaline dikes related to the reactivation of WNW-ESE faults are compatible with this NE-SW extension, as are basic Early Cretaceous dikes related to the opening of the South Atlantic Ocean.

The characterization of the tectonic events responsible for the subsidence of the Camaquã Basin as extensional ones suggests that the basin was an interior rift formed after the Brasiliano orogenic episodes. The abundant strike-slip and rare reverse faults affecting the basin are related to the cessation of subsidence and, in some cases, basin inversion, bringing no relation with the origin 
of the basin. Preliminary data from the Itajaí and Castro basins, which are the two other largest basins of the system (Almeida et al. 2010), indicate compatible paleostress fields and suggest a regional nature for the recognized tectonic events.

The characterization of four events of brittle faulting with different paleostress fields in the time span between 600 and $530 \mathrm{Ma}$ reveals that the tectonic evolution of Southeastern South America after the main collisional episode of the Brasiliano Orogeny (c.a. $630 \mathrm{Ma}$ ) was far more complex than the previously accepted model of continued postorogenic compression causing strike-slip deformation. The rapid paleostress changes are most probably the consequence of the interplay between local extensional stresses possibly caused by thermal anomalies and the distal propagation of the compressional stresses induced by younger episodes of continental collision at the plate margins.

\section{ACKNOWLEDGMENTS}

We thank Professor Claudio Riccomini for the discussions and contributions and Fundação de Amparo à Pesquisa do Estado de São Paulo (FAPESP) for graduate scholarships and research grants (2000/11089-2, 2005/53522-8, 2006/506550, 09/53362-1, 2010/50902-2, 2010/51103-6). This study is a NAP GEO-SEDEX contribution with the institutional support of the University of São Paulo (PrPesq).

\section{RESUMO}

No Leste da América do Sul, um conjunto de bacias sedimentares que afloram do sul do Uruguai ao sudeste do Brasil formou-se após os eventos colisionais da Orogenia Brasiliana, registrando os eventos tectônicos que afetaram a região a partir do Mesoediacarano. O problema da distinção entre a tectônica formadora das bacias e os eventos deformacionais posteriores é aqui abordado através da análise de paleotensões de mais de 600 dados de falhas com estrias, obtidos principalmente na
Bacia Camaquã (Sul do Brasil), que foram classificados por nível estratigráfico e relações de corte entre estrias sobrepostas, e intergrados a dados estratigráficos e geocronológicos disponíveis. Nossos resultados revelam que a Bacia Camaquã teve origem em ao menos dois eventos distensivos, e que modificações rápidas no campos de tensões ocorreram na região alguns poucos milhões de anos após a colisão principal (c.a. $630 \mathrm{Ma}$ ), provavelmente em decorrência da interação entre esforços distensivos locais e os efeitos distais da contínua amalgamação de placas e terrenos nas margens da placa Gondwana, ainda em formação. Dados preliminares de paleotensões da Bacia de Castro e dados publicados da Bacia Itajaí sugerem que esses eventos tiveram um caráter regional.

Palavras-chave: Bacia do Camaquã, Ciências da Terra, Neoproterozoico, Análise de Paleotensões, Bacia Rift, Sul do Brasil.

\section{REFERENCES}

ALMEIDA FFM. 1969. Diferenciação tectônica da Plataforma Brasileira. In: XXIII Congresso Brasileiro de Geologia, Anais, volume 1, SBG, Salvador, p. 29-46.

ALMEIDA FFM, AMARAL G, CORDANI UG AND KAWASHITA K. 1973. The precambrian evolution of the South American Cratonic Margin South of Amazon River. In: Nairn AE and Stehli FG (Eds), The ocean basins and margins. New York 1: 411-446.

Almeida FFM, HASSUI Y, BRITO NEVES BB AND FUCK RA. 1981. Brazilian structural provinces: an introduction. Earth-Sci Rev 17: 1-21.

ALMEIDA RP. 2001. Evolução tectono-sedimentar da Formação Santa Bárbara na Sub-bacia Camaquã Ocidental. Master's thesis, Instituto de Geociências, Universidade de São Paulo, São Paulo, 160 p. (Unpublished).

ALMEIDA RP. 2005. Tectônica e sedimentação do Ediacarano ao Ordoviciano: exemplos do Supergrupo Camaquã (RS) e do Grupo Caacupé (Paraguai Oriental). Ph.D. thesis, Instituto de Geociências, Universidade de São Paulo, São Paulo, 203 p.

ALMEIDA RP, JANIKIAN L, FRAGOSO-CESAR AR AND FAMBRINI GL. 2010. The Ediacaran to Cambrian rift system of Southeastern South America: tectonic implications. J Geol 118: 145-161.

ALMEIDA RP, JANIKIAN L, FRAGOSO-CESAR AR AND MARCONATO A. 2009. Evolution of a rift basin dominated by subaerial deposits: The Guaritas Rift, Early Cambrian, Southern Brazil. Sediment Geol 217: 30-51.

ANGELIER J. 1979. Determination of the mean principal directions of stress for a given fault population. Tectonophysics 56: $17-26$ 
ANGELIER J. 1984. Tectonic analysis of fault slip data sets. J Geophys Res 89: 5835-5848.

ANGELIER J. 1990. Inversion of field data in fault tectonics to obtain the regional stress. II: A new rapid direct inversion method by analytical means. Geophys J Int 103: 363-376.

Babinski M, Chemale Jr F, Hartmann LA, VAN SChmus WR AND SILVA LC. 1996. Juvenile accretion at 750-700 Ma in southern Brazil. Geology 24: 439-442.

BASEI MAS, Siga JR O, CORDANi UG, SATO K AND LiMA PS. 1999. The Magmatism of the Itajaí Basin, SC, Southern Brasil, and its importance to define the ProterozoicPhanerozoic limit. In: II South American Symposium on Isotope Geology, Actas, Cordoba, Argentine, p. 287-290.

BASEi MAS, Siga Jr O, MASquelin H, Harara OM, Reis Neto JM AND PREciozzI FP. 2000. The Dom Feliciano Belt of Brasil and Uruguay and its foreland domain, the Rio de La Plata Craton: framework, tectonic evolution and correlation with similar provinces of Southwestern Africa. In: CORDANI UG, MILANI EJ, THOMAZ FILHO A AND CAMPOS DA (Eds), Tectonic Evolution of South America, $31^{\text {st }}$ International Geological Congress, Rio de Janeiro, p. 311-334.

BASILICI G. 2006. Depositional mechanisms and architecture of a pre-early Cambrian mixed sand-mud deepwater ramp (Apiuna Unit, South Brazil). Sediment Geol 187: 183-204.

BonACIM EA, MORO RPX AND SOARES PC. 1994. Tectônica da bacia ordoviciana de Castro, Paraná. Boletim Paranaense de Geociências 42: 59-72.

Brito Neves BB, Campos Neto MC And Fuck R. 1999. From Rodinia to Eastern Gondwana: an approach to the Brasiliano-Pan African cycle and orogenic collage. Episodes 22: 155-166.

CAMPos Neto MC. 2000. Orogenic Systems from Southwestern Gondwana - an approach to Brasiliano-Pan African Cycle and Orogenic Collage in Southeastern Brazil. In: CORDANI UG, MILANI EJ, THOMAZ FILHO A AND CAMPOS DA (Eds), Tectonic Evolution of South America, Rio de Janeiro, $31^{\text {st }}$ International Geological Congress, Rio de Janeiro, p. 335-365.

Chemale JR F. 2002. Evolução Geológica do Escudo Sul-riograndense. In: HOLZ M and DE ROS LF (Eds), Geologia do Rio Grande do Sul, CIGO/UFRGS, p. 13-52.

Cordani UG, Basei MAS, Siga Jr O And Nutman A. 1999. Idades U-Pb (SHRIMP) de rochas vulcânicas das bacias de Campo Alegre, Itajaí e Castro (SC e PR). An Acad Bras Cienc 71: 835.

Cordani UG AND BRITO Neves BB. 1982. The geologic evolution of South America during the Archaean and Early Proterozoic. Rev Bras Geoc 12: 78-88.

DELVAUX D AND SPERNER B. 2003. Stress tensor inversion from fault kinematics indicators and focal mechanism data: the TENSOR program. In: Nieuwland D (Ed), New insights into structural interpretation and modelling, Geol Soc London Spec Publ 212: 75-100.
FAMBRINI GL. 1998. O Grupo Camaquã (Transição ProterozóicoFanerozóico) na região das Minas do Camaquã, RS: análise estratigráfica de fácies, proveniência e paleocorrentes. Master's thesis, Instituto de Geociências, Universidade de São Paulo, São Paulo, SP, 182 p. (Unpublished).

FAMBRINI GL. 2003. O Grupo Santa Bárbara (Neoproterozóico III) da Bacia do Camaquã, Rio Grande do Sul. Ph.D. thesis, Instituto de Geociências, Universidade de São Paulo, São Paulo, SP, 264 p.

FAMBrini GL, ALMEIDA RP AND FRAGOSO-CESAR ARS. 2006. Estratigrafia e evolução paleogeográfica do Grupo Santa Bárbara (Ediacarano) na sub-bacia Camaquã Ocidental, Rio Grande do Sul, Brasil. Rev Bras Geoc 36: 550-565.

FAMBRINI GLAND FrAGOSO-CESAR A. 2006. Análise estratigráfica do Grupo Santa Bárbara (Ediacarano) na Sub-Bacia Camaquã Oriental, RS. Rev Bras Geoc 36: 663-678.

FAMBRINI GL, FRAGOSO-CESAR ARS, RICCOMINI C, JANIKIAN L, Almeida RP AND Pelosi APMR. 2001. Tectônica extensional sin-deposicional na Formação Santa Bárbara, Bacia do Camaquã, RS (Neoproterozóico III-Cambriano Inferior). In: VIII Simpósio nacional de estudos tectônicos, Anais, SBG/ABGP, Recife, PE, p. 149-150.

FAMBRINI GL, JANIKIAN L, ALMEIDA RP AND FRAGOSO-CESAR ARS. 2005. O Grupo Santa Bárbara (Neoproterozóico III) na sub-bacia Camaquã Central, RS: sistemas deposicionais, paleogeografia e implicações tectônicas. Rev Bras Geoc 35(227-238): 227-238.

FAMBRINI GL, JANIKIAN L, ALMEIDA RP AND FRAGOSO-CESAR ARS. 2007. Evolução Estratigráfica e Paleogeográfica do Grupo Santa Bárbara na Sub-bacia Camaquã Central, RS. Geologia USP - Série Científica 7: 1-24.

FAMBrini GL, SAYEG HS AND FrAGOSO-CESAR ARS. 1992. Variação de áreas-fonte da Formação Arroio dos Nobres (Cambriano) no Vale do Arroio Boici, RS: análise estratigráfica de proveniência e de paleocorrentes. In: XXXVII Congresso Brasileiro Geologia, Boletim de Resumos Expandidos, volume 2, SBG, São Paulo, 441 p.

Fernandes LAD, Tommasi A AND Porcher CC. 1992. Deformation patterns in the southern Brazilian branch of the Dom Feliciano Belt: A reappraisal. J S Am Earth Sci 5: 77-96.

FonseCA MM, SILVEIRA AS, D’Ávila RSF, ZUCATTI DA ROSA AL, APPI CJ AND PAIM PSG. 2003. Arquitetura deposicional e fácies sedimentares do complexo turbidítico de Apiúna (Bacia do Itajaí - SC). In: PAIM PSG, FACCINI UF and NETTO RG (Eds), Geometria, arquitetura e heterogeneidades de corpos sedimentares: estudo de casos, UNISINOS, p. 122-146.

Fragoso-Cesar ARS. 1980. O Cráton Rio de La Plata e o Cinturão Dom Feliciano no Escudo Uruguaio-SulRiograndense. In: XXXI Congresso Brasileiro de Geologia, Anais, volume 5, SBG, Camboriú, SC, p. 2879-2892.

Fragoso-Cesar ARS. 1991. Tectônica de Placas no Ciclo Brasiliano: as orogenias dos Cinturões Dom Feliciano e Ribeira no Rio Grande do Sul. Ph.D. thesis, Instituto de Geociências, Universidade de São Paulo, São Paulo, 366 p. 
Fragoso-Cesar ARS, Almeida RP, Fambrini GL, Pelosi APMR AND JANIKIAN L. 2003. A Bacia Camaquã: um sistema intracontinental anorogênico de rifts do Neoproterozóico III-Eopaleozóico no Rio Grande do Sul. In: I Encontro sobre a Estratigrafia do Rio Grande do Sul, Boletim de Resumos, SBG, Porto Alegre, RS, p. 139-144.

Fragoso-Cesar ARS, FAMBrini GL, Almeida RP, PElosi APMR, JANIKIAN L, RICCOMINI C, MACHADO R, NogueIRA ACR AND SAES GS. 2000. The Camaquã extensional basin: Neoproterozoic to early Cambrian sequences in southernmost Brazil. Rev Bras Geoc 30: 438-441.

FRAGOSO-CESAR ARS, FAMBRINI GL, RICCOMINI C, JANIKIAN L, Almeida RP, Pelosi APMR and Machado R. 2001. Estruturas induzidas por abalos sísmicos na Formação Santa Bárbara (Neoproterozóico III - Eocambriano), Bacia do Camaquã, RS: o exemplo do Passo da Capela. Rev Bras Geoc 31: 155-162.

Fragoso-CESAR ARS, Wernick E AND SOLIANI JR E. 1982a. Associações petrotectônicas do Cinturão Dom Feliciano (SE da Plataforma Sul-Americana). In: XXXII Congresso Brasileiro de Geologia, number 1 in Anais, SBG, Salvador, BA, p. 1-12.

Fragoso-CESAR ARS, WERNICK E AND SOLIANI JR E. 1982 b. Evolução geotectônica do Cinturão Dom Feliciano - Uma contribuição através da aplicação do modelo da Tectônica de Placas. In: XXXII Congresso Brasileiro de Geologia, number 1 in Anais, SBG, p. 13-23.

FRIMMEL HE AND FRANK KW. 1998. Neoproterozoic tectonothermal evolution of the Gariep Belt and its basement, Namibia/South Africa. Precambrian Res 90: 1-28.

Gresse PG, Chemale Jr F, Silva LC, Walraven F and HARTMANN LA. 1996. Late- to post-orogenic basins of the Pan-African-Brasiliano collision orogen in southern Africa and southern Brazil. Basin Res 8: 157-171.

Gualda GA And Vlach SR. 2007a. The Serra da Graciosa A-type Granites and Syenites, southern Brazil: Part 2: Petrographic and mineralogical evolution of the alkaline and aluminous associations. Lithos 93: 310-327.

GuALDA GAR AND VLACH SRF. 2007b. The Serra da Graciosa A-type granites and syenites, southern Brazil. Part 1: regional setting and geological characterization. An Acad Bras Cienc 79: 405-430.

Hartmann LA, Leite JAD, Silva LC, Remus MVD, MCNAUGHTON NJ, GROVES DI, FLETCHER IR, SANTOS JOS AND VASCONCELLOS MAZ. 2000. Advances in SHRIMP geochronology and their impact on understanding the tectonic and metallogenic evolution of southern Brazil. Aust J Earth Sci 47: 829-844.

HeILBRON MAND MACHADON. 2003. Timing of terrane accretion in the Neoproterozoic-Eopaleozoic Ribeira orogen (SE Brazil). Precambrian Res 125: 87-112.

Heilbron M, Pedrosa-Soares AC, Campos Neto MC, SILVA LC, TROUW RAJ AND JANASI VA. 2004. Província Mantiqueira. In: MANTESSO NETO V, BARTORELLI A, CARNEIRO CDR AND BRITO NEVES BB (Eds), Geologia do Continente Sul-Americano: Evolução da Obra de Fernando Flávio Marques de ALMEIDA, Beca, p. 203-234.
JANASI VA, LEITE RJ AND VAN SCHMUS WR. 2001. U-Pb chronostratigraphy of the granitic magmatism in the Agudos Grandes Batholith (west of São Paulo, Brazil) implications for the evolution of the Ribeira Belt. J S Am Earth Sci 14: 363-376.

JANIKIAN L. 2001. Evolução paleoambiental do Grupo Camaquã na região de Bom Jardim, Sub-Bacia Camaquã Central, RS. Master's thesis, Instituto de Geociências, Universidade de São Paulo, São Paulo, SP, 158 p. (Unpublished).

JANIKIAN L. 2004. Seqüências deposicionais e evolução paleoambiental do Grupo Bom Jardim e da Formação Acampamento Velho, Supergrupo Camaquã, Rio Grande do Sul. Ph.D. thesis, Instituto de Geociências, Universidade de São Paulo, São Paulo, SP, 189 p.

JANiKian L, Almeida RP, Fragoso-CESAR ARS, CORRÊA CRA AND PELOSI APMR. 2005. Evolução paleoambiental e seqüências deposicionais do Grupo Bom Jardim e Formação Acampamento Velho (Supergrupo Camaquã) na porção norte da Sub-Bacia Camaquã Ocidental. Rev Bras Geoc 35: 245-256.

JANIKIAN L, ALMEIDA RP, FRAGOSO-CESAR ARS AND FAMBRINI GL. 2003. Redefinição do Grupo Bom Jardim (Neoproterozóico III) em sua área-tipo: litoestratigrafia, paleogeografia e significado tectônico das sucessões vulcano-sedimentares do Supergrupo Camaquã, RS. Rev Bras Geoc 33: 349-362.

JANIKIAN L, ALMEIDA RP, FRAGOSO-CESAR ARS, MARTINS VTS, DANTAS EL, TOHVER E, MCREATH I AND D'AGRELLAFILHO MS. 2012. Ages (U-Pb SHRIMP and LA-ICP-MS) and stratigraphic evolution of the Neoproterozoic volcanosedimentary successions from the extensional Camaquã Basin, Southern Brazil. Gondwana Res 21: 466-482.

JANIKIAN L, ALMEIDA RP, TRINDADE RIF, FraGOSO-CESAR ARS, D'AGRELla-FILHO MS, DANTAS EL AND TOHVER E. 2008. The continental record of Ediacaran volcanosedimentary successions in southern Brazil and their global implications. Terra Nova 20: 259-266.

Jost H. 1981. Geology and Metallogeny of the Santana da Boa Vista Region, Southern Brazil. Unpublished PhD thesis, University of Georgia, Athens, GA, USA, 208 p.

LEITE RJ. 2003. Petrogênese e geocronologia U-Pb do magmatismo granítico tardi a pós-orogênico do Batólito Agudos Grandes (SP). Ph.D. thesis, Instituto de Geociências, Universidade de São Paulo, São Paulo, 218 p.

MACHADO R AND SAYEG HS. 1992. Aplicação da análise geométrica e cinemática nos falhamentos que condicionaram a bacia molássica do Arroio Boici, RS. In I Workshop Sobre as Bacias Molássicas Brasilianas, Boletim de Resumos Expandidos, SBG/UNISINOS, São Leopoldo, RS, p. 73-76.

Marconato A, Almeida RP, SANTos MGM, NóBrega JE AND SoUZA RB. 2009. Alluvial-eolian interaction in a Cambrian rift margin: the Pedra das Torrinhas and Pedra Pintada formations (Guaritas Group, RS). An Acad Bras Cienc 81: 819-836.

MEERT JG. 2001. Growing Gondwana and rethinking Rodinia: a paleomagnetic perspective. Gondwana Res 4: 279-288. 
Moro RPX. 2003. A Bacia Ordoviciana do Grupo Castro - PR. $\mathrm{Ph} . \mathrm{D}$. thesis, Instituto de Geociências, Universidade de São Paulo, São Paulo, 156 p.

Moro RPX, Bonacim E AND SOARES PC. 1993. Grupo Castro: conteúdo de uma bacia molássica pós-orogênica no cambro-ordoviciano paranaense. Acta Geológica Leopoldensia 37: 119-134.

Moro RPX, Bonacim E And SoARes PC. 1994. Geologia da Bacia de Castro. Boletim Paranaense de Geociências 42: 43-58.

NARDi LVS AND Lima EF. 2002. O Magmatismo Shoshonítico e Alcalino da Bacia do Camaquã - RS. In: Geologia do Rio Grande do Sul, CIGO/UFRGS, p. 119-131.

OLIVEIRA JMMT AND FERNANDES L. 1992. Bacias molássicas brasilianas, mito ou realidade? In: I Workshop Sobre as Bacias Molássicas Brasilianas, Boletim de Resumos Expandidos, SBG/UNISINOS, São Leopoldo, RS, p. 97-105.

OLIVEIRA JMMT AND FERNANDES LAD. 1991. Estágios finais da evolução do Cinturão Dom Feliciano: Tectônica e sedimentação da Formação Arroio dos Nobres. In: III Simpósio Nacional de Estudos Tectônicos, Boletim de Resumos Extensos, SBG, Rio Claro, SP, p. 58-59.

OyhantÇABal P, Siegesmund S, Wemmer K, FRei R AND LAYER P. 2007. Post-collisional transition from calcalkaline to alkaline magmatism during transcurrent deformation in the southernmost Dom Feliciano Belt (Braziliano-Pan-African, Uruguay). Lithos 98: 141-159.

PAIM PSG. 1994. Depositional Systems and Paleogeographical Evolution of the Camaquã and Santa Bárbara Basins, Brazil. Ph. D. thesis, Oxford, 277 p.

PAIM PSG AND SCHERER CMS. 2007. High-resolution stratigraphy and depositional model of wind- and waterlaid deposits in the ordovician Guaritas rift (Southernmost Brazil). Sediment Geol 202: 776-795.

PAim PSG, Chemale JR F AND Lopes RC. 2002. A Bacia do Camaquã. In: Holtz M AND DEROS LF (Eds), Geologia do Rio Grande do Sul, CIGO/UFRGS, p. 231-274.

Pedrosa-SoARES AC AND WieldMANN-LEONARdos C. 2000. Evolution of the Araçuaí Belt and its Connection to the Ribeira Belt, Eastern Brazil. In: CORDANI UG, MILANI EJ, THOMAZ FILHO A AND CAMPOS DA (Eds), Tectonic Evolution of South America, $31^{\text {st }}$ International Geological Congress, $1^{\text {st }}$ edition, Rio de Janeiro, RJ, p. 265-285.

Pelosi A And Fragoso-Cesar ARS. 2003. Proposta litoestratigráfica e considerações paleoambientais sobre o Grupo Maricá (Neoproterozóico III), Bacia do Camaquã, Rio Grande do Sul. Rev Bras Geoc 33: 137-148.

PHILIPP RP. 1998. A evolução geológica e tectônica do Batólito de Pelotas no Rio Grande do Sul. Ph.D. thesis, Instituto de Geociências, Universidade de São Paulo, São Paulo, SP, 255 p.

PHILIPP RPAND MACHADO R. 2001. Suítes graníticas do Batólito de Pelotas no Rio Grande do Sul: petrografia, tectônica e aspectos petrogenéticos. Rev Bras Geoc 31: 257-266.

PhILIPP RP, NARDI LVS AND BITENCOURT MF. 2002. O Batólito Pelotas no Rio Grande do Sul. In: Geologia do Rio Grande do Sul, CIGO/UFRGS, p. 133-160.
Pimentel MM, Fuck RA And Alvarenga CJS. 1996. PostBrasiliano (Pan-African) high-K granitic magmatism in Central Brazil: the role of Late Precambrian-early Palaeozoic extension. Precambrian Res 80: 217-238.

Porada H. 1979. The Damara-Ribeira Orogen of the PanAfrican-Brasiliano Cycle in Namibia (South West Africa) and Brazil as interpreted in terms of continental collision. Tectonophysics 57: 237-265.

Ribeiro M, Bocchi PR, FigueIREDo FILHo PM AND TESSARI RI. 1966. Geologia da Quadrícula de Caçapava do Sul, Rio Grande do Sul. Boletim 127, DNPM/DFPM, Rio de Janeiro, RJ, 232 p.

RIBEIROMANDFANTINELLM. 1978. Associações petrotectônicas do Escudo Sul-Riograndense: I Tabulação e distribuição das associações petrotectônicas do Escudo do Rio Grande do Sul. Ihneríngia, Série Geológica 5: 19-54.

RIBEIRO M AND TEIXEIRA CAS. 1970. Datações de rochas do Rio Grande do Sul e sua influência nos conceitos estratigráficos e geotectônicos locais. Inheríngia, Série Geológica 3: 109-120.

Rostirolla SP, AHrendt A, SOAREs PC AND CARMignANi L. 1999. Basin analysis and mineral endowment of the Proterozoic Itajaí Basin, south-east Brazil. Basin Res 11: 127-142.

Rostirolla SP, ALKMIM FF AND SOARES PC. 1992a. O Grupo Itajaí, Estado de Santa Catarina, Brasil: exemplo de sedimentação em uma bacia flexural de antepaís. Boletim de Geociências da PETROBRAS 6: 109-122.

ROSTIROLLA SP AND SOARES PC. 1992. Bacia do Itajaí: evolução tectonossedimentar de uma bacia molássica precoce. In: I Workshop Sobre as Bacias Molássicas Brasilianas, Boletim de Resumos Expandidos, SBG/UNISINOS, São Leopoldo, RS, p. 124-128.

Rostirolla SP, SoAres PC AND AlKmim FF. 1992b. Análise estrutural da tectônica deformadora da Bacia de Itajaí, Estado de Santa Catarina, Brasil. Boletim de Geociências da PETROBRAS 6: 123-147.

SANTOS MGM, ALMEIDA RP AND FRAGOSO-CESAR ARS. IN PRESS. Paleostress analysis on brittle structures from the Camaqua Mines (Santa Barbara Group, Camaqua Basin). Rev Bras Geoc.

Silva LC, MCnaughton NJ, ARMStrong R, Hartmann LA AND FLETCHER IR. 2005. The neoproterozoic Mantiqueira Province and its African connections: a zircon-based U-Pb geochronologic subdivision for the Brasiliano/Pan-African systems of orogens. Precambrian Res 136: 203-240.

SILVA FILHO WF. 1997. A Formação Guaritas na porção centrosudeste da Bacia do Camaquã-RS. Master's thesis, Instituto de Geociências, Universidade de São Paulo, São Paulo, 121 p. (Unpublished).

SOARES PC. 1987. Seqüências tecto-sedimentares e tectônica deformadora no centro-oeste do Escudo Paranaense. In: III Simpósio Sul-Brasileiro de Geologia, Atas, volume 2, SBG, Curitiba, p. 743-771.

SOARES PC. 1988. Tectônica colisional em torno do Bloco Paraná, Brasil. In: VII Congresso Latino-Americano de Geologia, Anais, volume 1, SBG, Belém, p. 63-79. 
SOMMER CA, Lima EF, NARdi LVS, FigueIREdo AMG AND PIEROSAN R. 2005. Potassic and Low- and High-Ti mildly alkaline volcanism In the Neoproterozoic Ramada Plateau, Southermost Brazil. J S Am Earth Sci 18: 237-254.

Teixeira AL, Gaucher C, Paim PSG, Fonseca MM, Parente CV, Silva Filho WF and Almeida AR. 2004. Bacias do Estágio da Transição da Plataforma SulAmericana. In: MANTESSO NETO V, BARTORELLI A, CARNEIRO CDR AND BRITO NEVES BB (Eds), Geologia do Continente Sul-Americano: Evolução da Obra de Fernando Flávio Marques de Alemeida, Beca, p. 487-537.

ToHVEr E, Trindade RIF, SOlum JG, HALl CM, RicCOMINI C AND NogueIRA AC. 2010. Closing the Clymene ocean and bending a Brasiliano belt: Evidence for the Cambrian formation of Gondwana, southeast Amazon craton. Geology 38: 267-270.

TOMBA CLB. 2006. Tectônica e sedimentação das coberturas triássicas isoladas sobre o Alto Estrutural de Rio Grande na região entre Santana da Boa Vista e Canguçu, RS. Monography, Instituto de Geociências, Universidade de São Paulo. (Unpublished).
Trein E AND FuCK RA. 1967. O Grupo Castro. Boletim Paranaense de Geociências 23: 257-305.

Trouw R, HEILBRon M, Ribeiro A, PACIULlo F, VALERIANO CM, Almeida JCH, TUPINAMBÁ M AND ANDREIS RR. 2000. The central Segment of the Ribeira Belt. In: CORDANI UG, MILANI EJ, THOMAZ FILHO A AND CAMPOS DA (Eds), Tectonic Evolution of South America - $31^{\text {st }}$ International Geological Congress, Rio de Janeiro, RJ, p. 287-310.

Zerfass H, Chemale JR F And Lavina E. 2005. Tectonic control of the Triassic Santa Maria Supersequence of the Paraná Basin, Southernmost Brazil, and its correlation to the Waterberg Basin, Namibia. Gondwana Res 8: 163-176.

Zerfass H, Chemale JR F, Schultz CL and Lavina E. 2004. Tectonics and sedimentation in Southern South America during Triassic. Sediment Geol 166: 265-292.

ZERFASS H, LAVINA E, SCHULTZ CL, GARCIA AJV, FACCINI UF AND Chemale JR F. 2003. Sequence stratigraphy of continental Triassic strata of Southernmost Brazil: a contribution to Southwestern Gondwana palaeogeography and palaeoclimate. Sediment Geol 161: 85-105. 